\title{
Coordinated homeostasis of essential mineral nutrients: a focus on iron
}

Marc Hanikenne ${ }^{1}$, Sara M. Esteves ${ }^{1}$, Steven Fanara ${ }^{1}$, Hatem Rouached ${ }^{2,3,4}$

${ }^{1}$ InBioS - PhytoSystems, Functional Genomics and Plant Molecular Imaging, University of Liège, 4000 Liège, Belgium

${ }^{2}$ BPMP, Univ Montpellier, CNRS, INRA, Montpellier SupAgro, Montpellier, France

${ }^{3}$ Department of Plant, Soil, and Microbial Sciences, Michigan State University, East Lansing, MI 48824, USA

${ }^{4}$ Plant Resilience Institute, Michigan State University, East Lansing, MI 48824, USA

To whom correspondence should be addressed: Dr. Marc Hanikenne, InBioS - PhytoSystems, Functional Genomics and Plant Molecular Imaging, University of Liège, Quartier de la Vallée, 1, Chemin de la Vallée, 4 - Bât B22 4000 Liège, Belgium. Telephone: +32-4-3663844; Fax: +32-43662960; E-mail: marc.hanikenne@uliege.be

\section{Highlight}

Considering how the regulation of nutrient homeostasis networks is interconnected to determine growth in plants is topical. This review focuses on iron and its interactions with other macro- and micronutrients.

(C) The Author(s) 2020. Published by Oxford University Press on behalf of the Society for Experimental Biology. All rights reserved. For permissions, please email: journals.permissions@oup.com 


\section{Abstract}

In plants, iron (Fe) transport and homeostasis are highly regulated processes. Fe deficiency or excess dramatically limit plant and algae productivity. Interestingly, complex and unexpected interconnections between $\mathrm{Fe}$ and various macro- and micronutrient homeostatic networks, supposedly maintaining general ionic equilibrium and balanced nutrition, are currently uncovered. Although these phenomena have profound consequences on our understanding of Fe homeostasis and its regulation, the molecular bases and biological significance of these interactions remain poorly understood. Here, we review recent knowledge gained on how Fe interacts with micronutrient (e.g. zinc, manganese) and macronutrient (e.g. sulfur, phosphate) homeostasis, and on how these interactions affect Fe uptake and trafficking. We finally highlight the importance of developing an improved model of how Fe signaling pathways are integrated into functional networks to control plant growth and development in response to fluctuating environments.

\section{Keywords:}

Iron, iron deficiency, iron uptake, nutrient interaction, ion signaling crosstalk, nicotianamine, mugineic acid, root growth 


\section{Introduction}

Iron (Fe) is an essential element for all living organisms (Kobayashi and Nishizawa, 2012). Plants and algae are an important source of Fe entry in the terrestrial and aquatic food web, respectively. However, although it is abundant in the environment, $\mathrm{Fe}$ is poorly available to plants in soils (Marschner, 2012), and hence Fe deficiency is a major issue limiting crop productivity, as well as the quality of agricultural products. Similarly, algae primary productivity is severely impaired by low Fe availability in the open ocean (Sunda et al., 1991; Strzepek and Harrison, 2004). Consequently, Fe deficiency threatens human health. Indeed, according to WHO (http://www.who.int/nutrition/en/), one third of the human population worldwide is affected by Fe deficiency anemia. Therefore, there is an urgent need to better understand how photosynthetic organisms regulate Fe homeostasis.

In plant cells, while Fe can also be found in substantial amount in the nucleolus (Roschzttardtz et al., 2011), up to $80 \%$ of cellular Fe is found in chloroplasts in leaves (Terry and Abadia, 1986) and Fe represents $>60 \%$ of micronutrients in plant mitochondria (Tan et al., 2010), where it is found associated to heme and iron-sulfur clusters or as a cation. Photosynthesis and respiration therefore require adequate Fe supply and are highly sensitive to Fe deficiency (Nouet et al., 2011; Hanikenne et al., 2014; Vigani and Hanikenne, 2018). Adequate Fe supply is also required for several developmental processes, including for instance root growth, flowering or pollen production (Briat et al., 2015a; Bouain et al., 2019b). Fe deficiency is thus deleterious for the functioning of plant cells. In contrast, the redox properties that make Fe an essential cofactor of multiple biological processes can be harmful when Fe is delivered to cells in excessive amounts or if its interactions with biological macromolecules are uncontrolled (Stohs and Bagchi, 1995; Marschner, 2012). Therefore, plants possess sophisticated mechanisms, referred to as Fe homeostasis, to adjust, within a range of Fe supply, Fe uptake and distribution to needs throughout their development and upon changes in their environment (Kobayashi and Nishizawa, 2012; Thomine and Vert, 2013; and this special issue).

In addition to Fe, 13 mineral (micro- and macro-)elements are also essential for plant growth and development, whereas 5 others are considered beneficial (Marschner, 2012). Plants require an optimal and properly balanced supply of these elements. Nevertheless, in nature, plants can encounter multiple combinations of nutrient excesses and/or limitations. So far, the bulk of experimental studies mainly focused on the responses of plants to variation in the supply of a single element. This enables the detailed dissection of the molecular homeostasis mechanisms for these elements, identifying transporters, chelators, assimilation pathways, as well as a number of (transcriptional) regulators and to a lower extent sensing and signaling mechanisms. More recently, research opened to the investigation of interactions between nutrient homeostatic networks at the molecular level, revealing (i) multiple ways of nutrient inter-dependency: an element may be 
required for the proper uptake of another, deficiency or excess of one element impacts positively or negatively the uptake another, elements share pathways (e.g. transporters or chelators with broad specificity) or regulatory processes and (ii) hidden responses that are more than the addition of single stress responses (Bouain et al., 2019b). Those networks need to be examined in more detail to better comprehend the challenges faced by plants in their natural environments during their lifetime. This will enable the design of integrated and sustainable approaches to ensure plant production and quality.

Here, we present recent findings on the role of $\mathrm{Fe}$ in regulating complex developmental processes in plants, with a focus on the regulation of primary root growth. We then review our current knowledge on the molecular mechanisms orchestrating homeostatic interactions of Fe with other micro- and macronutrients in vascular plants, pinpointing whenever possible commonalities and differences between monocots and dicots. Finally, we also present a brief overview of those interactions in algae in comparison to higher plants, highlighting originalities found in algae (Box 1). Gaining new insight on how plants regulate Fe homeostasis will likely help to improve crop production on Fe-poor soils and to meet the challenge of global population growth and increasing demand for biofortified food.

\section{Regulation of primary root growth by iron availability}

Fe uptake from the soil is mediated by the root system (Dubeaux et al., 2015). Root-related processes are major targets of responses to changing Fe availability in the rhizosphere (Fig. 1). Fe deficiency or excess imposes drastic changes on the root system architecture, which varies within and between plant species (Gruber et al., 2013). This supports the potential for discovering key genes and signaling pathways by screening for phenotypic diversity in Fe stress responses across plant ecotypes and accessions, using quantitative genetic approaches (Dubeaux et al., 2015; Rouached and Rhee, 2017). Recently, genome-wide association studies (GWAS) were employed in the discovery of genes underpinning the root architecture in response to either Fe limitation or excess, in the model plant Arabidopsis thaliana (Arabidopsis). FRO2 (FERRIC REDUCTASE OXIDASE 2) was indeed identified as a gene responsible for the regulation of primary root growth (PRG) in response to Fe deficiency (Satbhai et al., 2017). PRG variation in Fe-deficient conditions is explained by sequence variation of the $F R O 2$ locus that causes differential gene expression, as well as ferricchelate reductase activity (Satbhai et al., 2017). The same GWAS approaches were used more recently to identify additional genes involved in the control of root growth rate in response to $\mathrm{Fe}$ deficiency in Arabidopsis. Several candidate genes were identified, although their functional 
validation and the discovery of causal polymorphisms await future study (Bouain et al., 2019a). GWAS has also been employed to identify loci associated with the natural variation of root growth in response to Fe toxicity. In this context, a causal gene named S-NITROSOGLUTATHIONE-REDUCTASE (GSNOR) was identified and characterized as essential in determining root growth in high $\mathrm{Fe}$ conditions (Li et al., 2019). Plants with a non-functional GSNOR gene display higher Fe tolerance than plants with functional alleles. This mechanism appears to be related to the activities of a gaseous molecule, nitric oxide (NO). GSNOR likely plays a central role in NO metabolism and regulates the plant's ability to respond to cellular stress and damage (Li et al., 2019). It has been proposed that in response to high Fe concentrations, the NO levels increase, impairing the tolerance of the plant roots (Li et al., 2019). This mechanism is likely conserved between monocots and dicots, but it remains to be confirmed if this mechanism can be generalized to all higher plants. GSNOR and NO signaling contribute to salt stress response in the green alga Chlamydomonas, but have not been tied to Fe homeostasis (Chen et al., 2016).

\section{Iron and micronutrient interactions: root uptake}

The interactions of Fe homeostasis with other micronutrients [e.g. zinc $(\mathrm{Zn})$, manganese $(\mathrm{Mn})$ ] or toxic and non-essential metal cations [e.g. cadmium (Cd)] are strongly dependent on the Fe uptake mechanisms, which can come in two different flavors in plants (Fig. 2) and are even more diversified in algae (Box 1). In dicot plants such as Arabidopsis exists a reduction-based strategy (or Strategy I) where $\mathrm{Fe}^{2+}$ is taken-up by cells, whereas chelation and uptake of chelated $\mathrm{Fe}^{3+}$ (Strategy II) is found in graminaceous monocots, i.e. grasses (Marschner and Römheld, 1994). Both strategies however share many molecular actors (see below and Grillet and Schmidt, 2019). Unchelated $\mathrm{Fe}^{3+}$ is also taken up directly in many algae (Box 1) (Blaby-Haas and Merchant, 2017). Both strategies of $\mathrm{Fe}^{2+}$ or $\mathrm{Fe}^{3+}$ uptake coexist in several species, rice or Chlamydomonas for instance (see below and Box 1) (Blaby-Haas and Merchant, 2017; Kobayashi et al., 2019). Divalent metal cations $\left(\mathrm{Zn}^{2+}, \mathrm{Mn}^{2+}, \mathrm{Cd}^{2+}\right)$ will therefore have a higher impact on Fe homeostasis in plants using the reduction strategy and $\mathrm{Fe}^{2+}$ uptake. For instance, $\mathrm{Zn}$ excess in Arabidopsis results in shoot chlorosis, reduced shoot $\mathrm{Fe}$ accumulation and more generally in the induction of a secondary Fe deficiency. These $\mathrm{Zn}$ toxicity symptoms result from competition for uptake as well as for Fe binding sites in proteins (e.g. involved in respiration and photosynthesis), and are alleviated by elevated Fe supply (Fukao et al., 2011; Shanmugam et al., 2011; Zargar et al., 2015; Lešková et al., 2017). Conversely, Fe deficiency results in increased shoot accumulation of $\mathrm{Zn}$, but also $\mathrm{Mn}$ and cobalt (Co) (Baxter et al., 2008). Such interactions were also documented in multiple dicot species in addition to Arabidopsis (Foy et al., 1978; Broadley et al., 2007), for instance Brassica rapa (Li et al., 2014) or Poplar (Ariani et al., 2015). 
In Arabidopsis, upon acidification of the soil (Santi and Schmidt, 2009) and reduction of $\mathrm{Fe}^{3+}$ into $\mathrm{Fe}^{2+}$ by FRO2 (Robinson et al., 1999), $\mathrm{Fe}^{2+}$ is taken up in root epidermal cells by IRT1 (IRON-REGULATED TRANSPORTER 1), a transporter of the ZIP (ZINC-REGULATED AND IRON-REGULATED-like PROTEINS) family (Fig. 2A). IRT1 is a high affinity transporter but has a low specificity: in addition to $\mathrm{Fe}^{2+}$, it transports a range of other divalent metal cations, including $\mathrm{Zn}^{2+}, \mathrm{Mn}^{2+}, \mathrm{Co}^{2+}, \mathrm{Ni}^{2+}$ and $\mathrm{Cd}^{2+}$ (Eide et al., 1996; Vert et al., 2002; Nishida et al., 2011). IRT1 is a major contributor to the interaction of Fe homeostasis with other metal cations, in such a way that back-up systems are implemented in the Fe deficiency response to accommodate the IRT1-mediated non-specific uptake of non-Fe metal cations. Hence, up-regulation of HMA3 (HEAVY METAL ATPASE 3, Morel et al., 2009), MTP3 (METAL TOLERANCE PROTEIN 3, Arrivault et al., 2006), MTP8 (Eroglu et al., 2016) and FPN2 (FERROPORTIN2, Schaaf et al., 2006; Morrissey et al., 2009) upon Fe deficiency ensures increased vacuolar storage capacity of, respectively, $\mathrm{Zn} / \mathrm{Cd}, \mathrm{Zn}, \mathrm{Mn}$ and $\mathrm{Co} / \mathrm{Ni}$ in root vacuoles, thus effectively limiting their toxicity in roots and their root-to-shoot translocation, whereas IRT2 ensures buffering of Fe itself in intracellular vesicles (Vert et al., 2009). This back-up system is coordinated by the complex action of the master Fe deficiency regulator FIT (FER-like IRON-DEFICIENCY-INDUCED TRANSCRIPTION FACTOR) and a multi-layer combination of additional transcription factors [e.g. more than $14 \mathrm{bHLH}$ (BASIC HELIX-LOOP-Helix) proteins, 2 MYB (MYELOBLASTOSIS)] and regulators [e.g. E3 Ubiquitin Ligases BTS (BRUTUS) and BTS-like targeting proteins for proteasome degradation], as well as hormonal control (e.g. by jasmonic acid, ethylene or gibberellins) and NO signaling. These processes have been extensively detailed in recent reviews (see for instance Brumbarova et al., 2015; Buet and Simontacchi, 2015; Rodríguez-Celma et al., 2019; Kobayashi et al., 2019; Wu and Ling, 2019 and this special issue). Recently, FBP (FIT-BINDING PROTEIN) was shown to control FIT activity, and to play an important role in fine-tuning Fe and Zn interactions (Chen et al., 2018). In addition, the IRT1 protein itself is also subjected to a complex regulation by not only Fe but also by non-Fe metals ( $\mathrm{Zn}, \mathrm{Mn}, \mathrm{Co})$, at the transcriptional and post-transcriptional levels (Connolly et al., 2002; Fukao et al., 2011; Shanmugam et al., 2011). Internalization of IRT1 from the plasma membrane upon ubiquitination followed by its recycling to the plasma membrane or its targeting for degradation in vacuoles is regulated by non-Fe metal ( $\mathrm{Zn}, \mathrm{Mn}, \mathrm{Co})$ availability to ensure proper balance between Fe uptake and the hazardous effects of excessive uptake of other divalent metals (Barberon et al., 2011, 2014; Dubeaux et al., 2018).

Evidence is accumulating that the broad specificity of IRT1 plays also a role in metal uptake in socalled metal hyperaccumulator plants (Krämer, 2010; Hanikenne and Nouet, 2011; Merlot et al., 2018) and that IRT1 may be a major determinant of the intraspecific variation of the trait. Indeed, variation of IRT1 gene expression or function is linked to (i) variation in $\mathrm{Zn}$ and/or Cd shoot 
accumulation among populations of the $\mathrm{Zn} / \mathrm{Cd}$ hyperaccumulators Arabidopsis halleri (Corso et al., 2018; Schvartzman et al., 2018) and Noccaea caerulescens (Halimaa et al., 2019); and (ii) Ni shoot accumulation in Ni-hyperaccumulating populations of $N$. caerulescens (Halimaa et al., 2014a,b) and in Senecio coronatus (Meier et al., 2018). More generally, exposure to high metal levels and metal hyperaccumulation itself interferes with Fe homeostasis (Talke et al., 2006; Krämer et al., 2007; Lin et al., 2009; Willems et al., 2010; Sinclair and Krämer, 2012; Charlier et al., 2015), and maintaining Fe homeostasis is thus key in hyperaccumulator species. This is achieved, in at least some populations or species, by inducing an Fe deficiency response, which mobilizes specific parts of the multi-layer regulation pathway found in Arabidopsis (Shanmugam et al., 2011; Corso et al., 2018; Schvartzman et al., 2018).

If Fe deficiency results in $\mathrm{Zn}, \mathrm{Co}$ and $\mathrm{Cd}$ accumulation in Arabidopsis shoots (Col- 0 accession), it has the opposite effect on molybdenum (Mo) shoot accumulation (Baxter et al., 2008). Indeed, the acidification of the medium associated to the Fe uptake strategy 1 limits Mo bioavailability (Marschner, 2012). In addition, several micro-RNAs initially identified as major players on $\mathrm{Cu}$ homeostasis (Pilon 2017) were recently shown to also be linked to Fe homeostasis, by controlling the oxidative stress response and oxidative metabolic processes (Carrió-Seguí et al., 2019; Waters et al., 2012).

In grasses, Fe acquisition involves the secretion of mugineic acid family (MA) phytosiderophores, high affinity $\mathrm{Fe}^{3+}$ chelators able to solubilize Fe from the soil (Fig. 2B) (Marschner and Römheld, 1994; Kobayashi and Nishizawa, 2012). Upon synthesis from S-adenosyl-L-methionine (SAM), with nicotianamine (NA, see below) as intermediate, MA are secreted into the soil by TOM1 (TRANSPORTER OF MUGINEIC ACID FAMILY PHYTOSIDEROPHORES 1) (Nozoye et al., 2011). MA$\mathrm{Fe}(\mathrm{III})$ complexes are then taken-up by YS1/YSL transporters (YELLOW-STRIPE 1/YS-Like) (Curie et al., 2001; Inoue et al., 2009). This strategy is particularly advantageous on calcareous soils where high $\mathrm{pH}$ reduces strongly Fe availability (Marschner and Römheld, 1994). Many commonalities have been found between the regulation of the Fe deficiency response in dicots and grasses, including the involvement of bHLH transcription factors and E3 Ubiquitin Ligases, but with also some differences, including the key role of IDEF1 and IDEF2 (IRON DEFICIENCY-RESPONSIVE ELEMENT BINDING FACTOR) transcription factors in transcriptional regulation and Fe status sensing in rice (for detailed reviews, see Kobayashi and Nishizawa, 2012, 2015; Kobayashi et al., 2019).

Rice (Oryza sativa) has been the most used model to uncover metal homeostasis mechanisms in grasses. However, in contrast to other graminaceous plants, it uses a Fe uptake strategy, which possibly evolved prior to rice domestication (Wairich et al., 2019), combining elements of both reduction and chelation strategies and this may have biased our view on how Fe homeostasis takes 
place in grasses. Indeed, OsIRT1 and OsIRT2, two proteins related to the Arabidopsis IRT1 protein (Evens et al., 2017), are involved in $\mathrm{Fe}^{2+}$ uptake, in the absence of both acidification by $\mathrm{H}^{+}$-ATPase and ferric-chelate reductase activity. The two corresponding genes are highly induced upon Fe deficiency. In addition to the chelation strategy, direct uptake of $\mathrm{Fe}^{2+}$ comes handy in paddy fields, which have low oxygen and high $\mathrm{Fe}^{2+}$ levels (Ishimaru et al., 2006; Cheng et al., 2007). It possibly comes at a cost of specificity as overexpression of OsIRT1 in rice not only results in increased accumulation of $\mathrm{Fe}$, but also of $\mathrm{Zn}$ and $\mathrm{Cd}$ in root and shoot tissues, and in higher sensitivity to high $\mathrm{Zn}$ and $\mathrm{Cd}$ exposure (Lee and An, 2009). OsIRT1 and OsIRT2 were suggested to contribute to higher Cd accumulation upon Fe deficiency (Nakanishi et al., 2006). In contrast to its Arabidopsis homolog, however, the OSIRT1 transcript level is not induced by $\mathrm{Zn}$ excess, suggesting a distinct impact of $\mathrm{Zn}$ in the two species (Ishimaru et al., 2008). The combined strategy of Fe uptake is limited to rice and a few relatives (Ishimaru et al., 2008; Wairich et al., 2019). Although its genome contains an IRT1 homolog (Li et al., 2013; Evens et al., 2017) and genes putatively encoding an $\mathrm{H}^{+}$-ATPase and a ferricchelate reductase (Li et al., 2018), maize (Zea mays) is indeed strictly dependent on MA-Fe(III) uptake for Fe acquisition and survival, whereas rice plants unable to synthetize MAs are healthy when supplied with $\mathrm{Fe}^{2+}$ (Cheng et al., 2007). An IRT1 homolog is also found in barley (Evens et al., 2017), but is important for Mn uptake, and not Fe (Pedas et al., 2008).

Grasses are more sensitive to $\mathrm{Zn}$ toxicity than dicots, especially on calcareous soils. This observation can be linked to the Fe deficiency-induced production of phytosiderophores by roots that also strongly solubilizes $\mathrm{Zn}$ (Chaney, 1993). MAs were indeed shown to contribute to chelation and uptake of non-Fe metals, including $\mathrm{Zn}$ upon $\mathrm{Zn}$ deficiency in the form of MA-Zn(II), in barley and maize (von Wirén et al., 1996; Suzuki et al., 2006). In rice, secretion of MAs upon Zn deficiency is low compared to other grasses (Suzuki et al., 2008), but appears to be sufficient to account for Zn uptake in these conditions (Arnold et al., 2010; Ptashnyk et al., 2011; Marković et al., 2017). MAs are also involved in $\mathrm{Zn}$ translocation to shoot tissues in rice (Suzuki et al., 2008). In many cases, overexpression of elements of the MA synthesis, secretion, uptake or translocation pathways results in an increased Fe but also Zn content in rice grains (Bashir et al., 2013).

\section{Iron and micronutrient interactions: intracellular and long distance trafficking}

In addition to uptake, Fe and micronutrient intracellular trafficking and long distance distribution within the plant is mediated by common metal chelators and (chelated) metal transporters (Fig. 2). For instance, the ZIP transporter IRT3 is a plasma-membrane located Zn and Fe transporter in Arabidopsis, and was therefore suggested to contribute to cellular uptake of Fe and $\mathrm{Zn}$ (Lin et al., 2009). The IRT3 gene is induced by Zn deficiency (Talke et al., 2006) but not by Fe deficiency (Yang et al., 2010), and its expression level, together with that of ZIP4, has been linked to variation of $\mathrm{Zn}$ 
deficiency tolerance among Arabidopsis accessions (Campos et al., 2017). IRT3 is also associated with a quantitative trait locus for Fe accumulation in shoots of $A$. halleri, suggesting that it may contribute to maintenance of Fe homeostasis in the Zn/Cd hyperaccumulator (Willems et al., 2010). Several other Arabidopsis ZIP transporters were shown to transport Fe and $\mathrm{Zn}$ (ZIP3) or to be regulated by both the Fe and Zn status of the plant (ZIP10, ZIP11, ZIP12) (Shanmugam et al., 2013), but as for most ZIP transporters in plants, their individual contributions to metal homeostasis remain largely unknown (Ricachenevsky et al., 2015).

Transporters of the NRAMP (NATURAL RESISTANCE-ASSOCIATED MACROPHAGE PROTEIN) family are also tying Fe to other microelements, such as Mn and $\mathrm{Zn}$. Indeed, the Arabidopsis NRAMP1 was shown to transport Mn and Fe in yeast (Thomine et al., 2000; Curie et al., 2000), and to be the main Mn uptake system in plant roots (Cailliatte et al., 2010; Bian et al., 2018). NRAMP1 also contributes to Fe uptake together with IRT1 (Castaings et al., 2016). As IRT1 (see above), NRAMP1 undergoes intracellular trafficking, involving a phosphatidylinositol 3-phosphate-binding protein, with a localization on endomembranes or the plasma membrane, possibly enabling the fine-tuning of $\mathrm{Fe}$, and Mn, uptake (Agorio et al., 2017). Higher expression of NRAMP1 has been associated with higher shoot Cd accumulation among rice (Takahashi et al., 2011a,b) or N. caerulescens (Milner et al., 2014) accessions. In rice and possibly other monocots, NRAMP5, primarily a Mn transporter, is a major determinant of $\mathrm{Cd}$ accumulation in grains (reviewed in Clemens, 2019).

NRAMP3 and NRAMP4 are two additional $\mathrm{Fe}$ and Mn transporters, localized in the vacuolar membrane in Arabidopsis. Together, they are essential for Fe mobilization from vacuoles during seed germination (Lanquar et al., 2005), and for providing sufficient Mn for the photosynthetic apparatus in mature leaves (Lanquar et al., 2010). Both proteins are furthermore contributing to $\mathrm{Zn}$ and $\mathrm{Cd}$ tolerance by mediating appropriate $\mathrm{Fe}$ and $\mathrm{Mn}$ supply to chloroplasts, thus maintaining the photosynthetic function when exposed to $\mathrm{Zn}$ excess or Cd (Molins et al., 2013). NRAMP3 is overexpressed in $A$. halleri and $N$. caerulescens, suggesting a contribution to $\mathrm{Zn} / \mathrm{Cd}$ hypertolerance or hyperaccumulation (Talke et al., 2006; van de Mortel et al., 2006; Oomen et al., 2009). The NRAMP3 gene is further associated with a $\mathrm{Zn}$ tolerance QTL for photosynthetic yield in a F2 progeny of an intraspecific cross in A. halleri (Karam et al., 2019). The counterpart of NRAMP3 and NRAMP4 in Arabidopsis is VIT1, which is key for Fe vacuolar storage in seeds (Kim et al., 2006). In rice, two VIT1 homologs (OsVIT1 and OsVIT2) are vacuolar transporters of Fe and Zn, and are responsible for vacuolar storage of these metals in flag leaf blade and sheath, and consequently controlling the transfer of both elements to grains (Zhang et al., 2012).

Both inter- and intra-cellular movements of Fe and other metals (e.g. $\mathrm{Zn}, \mathrm{Mn}$ ) are facilitated by the production of common chelating compounds such as the organic acid citrate and NA, with which 
these metals form soluble complexes (Morrissey and Guerinot, 2009; Sinclair and Krämer, 2012; Flis et al., 2016). In grasses, MA phytosiderophores are additionally contributing to these processes (Suzuki et al., 2008; Kobayashi and Nishizawa, 2012). The production and subcellular distribution of these metal chelator molecules are affected by metal availability. It is indeed well known that Fe deficiency and $\mathrm{Zn}$ excess both result in increased concentration of citrate in roots (i.e. in the xylem sap) (López-Millán et al., 2000; Sarret et al., 2002). Citrate has an optimum chelating capacity and forms more stable complexes at acidic $\mathrm{pH}$ (ranging from 5.5 to 6), a pH similar to that of the xylem sap (López-Millán et al., 2000; Ryan et al., 2001; Yoneyama et al., 2015). At this pH range, Fe is transferred from cytoplasmic NA to citrate upon loading in the xylem sap as [FeCitrateOH] $]^{-1}$ and $\left[\mathrm{FeCitrate}_{2}\right]^{-3}$ complexes (López-Millán et al., 2000; Ryan et al., 2001; Yoneyama et al., 2015). Similarly, Zn-citrate complexes are also largely present in the xylem sap (Cornu et al., 2015; Flis et al., 2016). Citrate loading into the xylem results from the activity of the citrate effluxer FRD3 (FERRIC REDUCTASE DEFECTIVE 3), a member of the MATE (MULTIDRUG AND TOXIC EFFLUX) family (Durrett et al., 2007), whose expression in Arabidopsis is not only induced upon Fe deficiency but also upon Zn excess in roots and Zn deficiency in shoots (Pineau et al., 2012; Charlier et al., 2015). frd3 mutant plants are small and chlorotic, and display constitutive overexpression of the strategy I Fe uptake machinery (see above) as well accumulation of Fe, $\mathrm{Mn}$ and $\mathrm{Zn}$ in tissues (Delhaize, 1996; Rogers and Guerinot, 2002; Green and Rogers, 2004; Durrett et al., 2007). In addition to severe Fe deficiency in shoot tissues, the growth defect of the frd3 mutant results from $\mathrm{Mn}$ toxicity as well as $\mathrm{Fe}$ accumulation-induced reactive oxygen species production and biotic stress response (Scheepers et al., 2020). Zn excess partially restores growth of the mutant, by abolishing Mn accumulation in shoot and Fe accumulation in the cell-wall in roots (Scheepers et al., 2020). This not only depicts the crosstalk between Fe and $\mathrm{Zn}$ homeostasis but also the role of FRD3 as an essential regulator of this interplay (Pineau et al., 2012; Scheepers et al., 2020). An homolog of FRD3 has been characterized in rice (OsFRDL1, FRD-Like 1) and shares a similar function in citrate efflux to the root xylem for Fe translocation to the shoots and in Fe distribution in panicles (Inoue et al., 2004; Yokosho et al., 2009, 2016; Yoneyama et al., 2015). However, osfrdl1 mutants do not display severe growth phenotypes as an Arabidopsis frd3 mutant (Yokosho et al., 2009), suggesting that chelators, in addition to citrate, are important for Fe translocation to shoot in rice. Hence, PEZ1 (PHENOLICS EFFLUX ZERO 1), a MATE transporter, is responsible for phenolic compound release into the xylem in rice roots contributing to Fe mobilization and long distance Fe translocation (Ishimaru et al., 2011). TOM2 (Nozoye et al., 2015) and ENA1 (EFFLUX TRANSPORTER OF NA 1) (Nozoye et al., 2019) are additionally required for efflux of DMA and NA into the apoplasm, respectively, and also contribute to Fe mobilization in this compartment. 
NA has a key function in the control of metal cellular levels in both monocots and dicots. The formation and the stability of the NA-metal complexes are optimal at $\mathrm{pH}$ above 6.5 , suggesting that NA serves as a chelator predominately enriched within cells and phloem sap where it contributes to compartmentalization of metals and long distance transport (von Wirén et al., 1999). NA is synthesized from SAM by NA SYNTHASE (NAS) enzymes (Pianelli et al., 2005; Haydon and Cobbett, 2007a). The Arabidopsis genome contains four NAS genes (AtNAS1-4), whose expression is upregulated upon Fe or Zn deficiency, as well as Zn excess (Colangelo and Guerinot, 2004; van de Mortel et al., 2006; Klatte et al., 2009; Chen et al., 2018). nas4x-1 and nas4x-2 quadruple mutants are sensitive to Fe deficiency but not $\mathrm{Zn}$ deficiency and are unable to properly distribute $\mathrm{Fe}$ and $\mathrm{Zn}$ to flowers due to the drastic reduction in NA levels, thereby resulting in sterility (Klatte et al., 2009; Schuler et al., 2011, 2012). NA levels are a key element controlling radial movements of metals in the roots, either favoring vacuolar storage or translocation to the shoots, two processes where Fe and $\mathrm{Zn}$ compete as well (Arrivault et al., 2006; Chen et al., 2018; Haydon et al., 2012). NA overaccumulation in $A$. thaliana results in increased sensitivity to Fe deficiency, but Ni resistance, as well as decreased levels of Fe in roots resulting from enhanced translocation of Fe to shoots, and $\mathrm{Zn}$ elevation in both roots and shoots (Pianelli et al., 2005; Kim et al., 2005; Cassin et al., 2009, Chen et al., 2018). It was also shown that an elevated production of NA is a key factor for $\mathrm{Zn}$ hyperaccumulation in A. halleri (Weber et al., 2004; Uraguchi et al., 2019).

Numerous proteins are involved in both the partitioning and long distance transport of NA-metal complexes. Two major facilitator superfamily transporters, ZIF1 and ZIF2 (ZINC-INDUCED FACILITATOR), localize to the tonoplast where they control the vacuolar storage of NA-chelated metals (i.e. $\mathrm{Fe}^{2+}, \mathrm{Fe}^{3+}, \mathrm{Zn}^{2+}$ ) in Arabidopsis (Beneš et al., 1983; von Wirén et al., 1999). ZIF1 plays a critical role in $\mathrm{Zn}$ detoxification under Fe deficiency (Haydon and Cobbett, 2007b), and omission of $\mathrm{Zn}$ from the media partially suppresses the growth defect of the Fe-deficient zif1-3 mutant (Haydon et al., 2012). ZIF1 expression is induced upon Zn excess (Haydon and Cobbett, 2007b) or Fe limitation (Haydon et al., 2012). Increased vacuolar partitioning of NA through ZIF1 overexpression leads to vacuolar $\mathrm{Zn}$ sequestration in roots and ultimately to decreased $\mathrm{Zn}$ shoot levels as a result of the impairment of both Zn symplastic mobility and xylem loading (Haydon et al., 2012). ZIF1 overexpressing plants also display reduced leaf cell-to-cell mobility of $\mathrm{Fe}$, leading to constitutive symptoms of Fe deficiency (Haydon et al., 2012). Higher expression of ZIF2 upon Zn excess leads to increased $\mathrm{Zn}$ tolerance thanks to favored root vacuolar $\mathrm{Zn}$ sequestration and prevention of NA-Zn translocation to shoots (Remy et al., 2014). In contrast to non-accumulator species that achieve root vacuolar sequestration of excessive metals when exposed to increased amounts of chelating 
compounds, hyperaccumulator species tend to favor the mobility of NA-chelated metal (i.e. $\mathrm{Zn}$ ) towards the xylem (Deinlein et al., 2012; Cornu et al., 2015).

Involved in the transport of both NA- and MA-metal complexes in monocots, the YSL function is restricted to the mobilization of NA-chelated metals (NA-Fe, $-\mathrm{Zn}$, -Ni or - $\mathrm{Cu}$ ) in dicots (Schaaf et al., 2004; Waters et al., 2006; Sinclair and Krämer, 2012). In Arabidopsis, the 8 YSL genes display differential patterns of regulation $\mathrm{Fe}, \mathrm{Zn}$ and $\mathrm{Cu}$ deficiency and/or excess (DiDonato et al., 2004; Schaaf et al., 2005; Le Jean et al., 2005; Waters et al., 2006; Conte et al., 2013). Single (ys/1) or double mutant (ys/1ys/3 and $y s / 4 y s / 6)$ plants mainly display alterations of NA and metal concentrations in tissues, characterized by increased levels of $\mathrm{Zn}, \mathrm{Mn}$ and $\mathrm{Cu}$, but reduced amount of $\mathrm{Fe}$, in leaves, as well as a subsequent deficiency of $\mathrm{Fe}, \mathrm{Zn}$ and $\mathrm{Cu}$ in seeds, leading to a low fertility (Le Jean et al., 2005; Waters et al., 2006; Chu et al., 2010; Conte et al., 2013).

In addition to citrate and NA, glutathione (GSH) is known to contribute to the crosstalk between $\mathrm{Zn}$ and Fe homeostasis in Arabidopsis. GSH is an antioxidant contributing to the ascorbateglutathione cycle that plays a role in Fe-mediated $\mathrm{Zn}$ tolerance. Indeed, a loss-of-function mutation in GSH1, which encodes a $\gamma$-glutamylcysteine synthetase involved in the biosynthesis of GSH, leads to increased sensitivity to $\mathrm{Zn}$ excess in the concomitant presence of additional Fe (Shanmugam et al., 2012). GSH also links Fe and Mo homeostasis. Indeed, the ATM3 (ABC TRANSPORTER OF THE MITOCHONDRIA 3) exports GSH-polysulfide out of the mitochondria and is required for the maturation of Fe-S cytosolic enzymes and for molybdenum cofactor (Moco) biosynthesis (Schaedler et al., 2014; Teschner et al., 2010). atm3 mutants are moreover sensitive to Cd (Hanikenne et al., 2005b; Kim et al., 2006).

\section{Iron and sulfur homeostasis interaction}

Evidence at the molecular and morphological levels in support of the interplay between Fe and sulfur (S) homeostasis is constantly growing. It has been shown that despite the presence of sufficient $S$ in the medium, Fe deficiency conditions lead to a $S$ deficiency response at the molecular level in durum wheat (Triticum turgidum L.; Ciaffi et al., 2013). Grasses (Strategy II plants) respond to Fe deficiency by secreting phytosiderophores into the rhizosphere, which are required for chelation as well as Fe uptake (see above). Interestingly, the release of these molecules is modulated by $\mathrm{S}$ availability: $\mathrm{S}$ deficiency reduces their release, whereas sulfate resupply enhances it in barley (Hordeum vulgare L.) (Astolfi et al., 2010; Ciaffi et al., 2013). On the other hand, Fe nutrition appears to affect $\mathrm{S}$ transport in plants, with Fe starvation increasing the expression of sulfate transporters, which enhances $S$ uptake from the soil and influences $S$ remobilization from the vacuole (Schuler et al., 2011; Couturier et al., 2013; Paolacci et al., 2014; Kaur et al., 2019). Fe also affects the $S$ distribution between roots and shoots. In leaves, Fe and $S$ are known to interact in the building of 
Fe-S clusters, which are a major sink for Fe and are known to be essential for photosynthetic electron transfer, chlorophyll metabolism, respiration, and many cellular enzymatic reactions (Couturier et al., 2013; Kaur et al., 2019). This suggests a tight coordination between the metabolisms of these two nutrients in support of vital plant biological processes. However, the mechanisms regulating the integrated homeostasis of these two elements remains to be deciphered.

While Fe limitation strongly reduces the total S content in both shoots and roots of tomato (Solanum lycopersicum) plants (Zuchi et al., 2015), S limitation causes a decrease in the Fe concentration in leaves. For instance, tomatoes grown under $-\mathrm{S}$ conditions display a reduction in Fe concentrations in comparison to plants grown under S-sufficient conditions. This low Fe accumulation could be explained by the reduction in Fe uptake capacity associated with a decrease in the expression and activity of the Fe uptake machinery. In dicots such as Arabidopsis, $\mathrm{S}$ deficiency strongly represses the expression of the high affinity Fe transporter IRT1 (Forieri et al., 2013). Interestingly, when challenged with both $S$ and Fe starvation, the expression of IRT1 is induced but to a lower extent compared to Fe deficiency conditions, which can be explained by a decreased requirement of Fe for Fe-S cluster synthesis under -S (Forieri et al., 2013). Finally, in tomato plants, the activity of Fe transporters is reduced suggesting that $S$ deficiency prevents the typical responses to Fe deficiency (Zuchi et al., 2009).

Beyond ion transport activity, Fe nutrition profoundly impacts $S$ assimilation in both graminaceous and non-graminaceous plants (Forieri et al., 2013; Briat et al., 2015b; Bouain et al., 2019b). For instance, in Arabidopsis, gene expression profiling has revealed that a number of genes involved in the $\mathrm{S}$ assimilation pathway are co-expressed with Fe-deficient genes in response to Fe deficiency (Schuler et al., 2011), suggesting that Fe availability partially controls the $S$ assimilation-related genes. This control is visible at the transcriptional, posttranscriptional, and protein activity levels. Altogether, these findings provide physiological and molecular evidence for a crosstalk between the Fe and S pathways in different plant species, with marked species specificities. These findings also reveal the presence of many transcriptional and posttranscriptional regulatory mechanisms that plants can use to adapt to Fe fluctuation by modulating their $\mathrm{S}$ homeostasis, and vice versa. Further investigations are now needed to decipher the molecular details of these mechanisms. 


\section{Iron and phosphate homeostasis interaction}

The interaction between Fe and phosphate $\mathrm{Pi}$ ) is well-recognized in soil as well as in plants (Müller et al., 2007; Thibaud et al., 2010; Briat et al., 2015b; Bouain et al., 2019b). Indeed, the complexation of Fe by $\mathrm{Pi}$ in the soil leads to the formation of precipitates, which decreases the availability of these two elements for plants (Briat et al., 2020). While low Pi availability in soil leads to the Fe overaccumulation in plants, the converse is also true (Misson et al., 2005; Hirsch et al., 2006; Müller et al., 2007; Thibaud et al., 2010). Indeed, plants have evolved a coordinated gene expression network in order to respond jointly to element deficiencies and/or excesses. For instance, gene expression profiling of $\mathrm{Pi}$-deficient plants revealed an increase in abundance of transcripts of both $\mathrm{Pi}$ starvation-related and Fe excess-responsive genes (Misson et al., 2005; Müller et al., 2007; Thibaud et al., 2010). Such examples can be seen in the remarkable induction of expression of AtFER1-4 mRNAs, which encode the Fe storage protein ferritin, accurately reflecting the increase in available Fe under Pi starvation conditions (Hirsch et al., 2006). Interestingly, AtFER1 higher expression appears to be mediated by PHOSPHATE RESPONSE 1 (PHR1) and PHR1-LIKE 1 (PHL1), key regulators of the phosphate starvation response (PSR) in plants, thus revealing a role for these transcriptions factors in the overall control of Fe homeostasis that is integrated with the Pi status of the plant (Bournier et al., 2013; Bouain et al., 2019b) (see also Box 1). Decades of research have helped to understand how plants respond to Pi deficiency, mainly in the roots, leading to the identification of a mechanism that is tightly linked to variation in Fe accumulation. Key genes involved in this process include the cell wall-targeted FERROOXIDASE (LPR1), a P5-type ATPase (PDR2), as well as the SENSITIVE TO PROTON RHIZOTOXICITY (STOP1) transcription factor and its target ALUMINUM ACTIVATED MALATE TRANSPORTER 1 (ALMT1) (Fig. 1). PDR2 controls LPR1 activity, which mediates Fe accumulation in the root tip. STOP1 upregulates ALMT1, which modulates exudation of malate (Müller et al., 2007; Thibaud et al., 2010; Balzergue et al., 2017;Mora-Macías et al., 2017), consequently promoting Fe deposition in the root. Thus these genes could be considered as Feresponsive genes, and they form two modules that act in concert to provoke Fe overaccumulation in roots, which is likely a primary cause of PRG inhibition under Pi deficiencies (Müller et al., 2007; Ward et al., 2008; Ticconi et al., 2009; Thibaud et al., 2010; Briat et al., 2015b; Bouain et al., 2019b). This is consistent with the fact that simultaneous Fe and Pi deficiencies restore PRG in Arabidopsis. This observation reveals that plants respond to the combined Fe and Pi stress in a manner distinct from individual Fe or Pi deficiencies (Bouain et al., 2019b). Key genes associated with this phenotype were recently identified and include VARIANT IN METHYLATION 1, FORMIN-LIKE-PROTEIN-6 and VOLTAGE-DEPENDENT ANION-SELECTIVE CHANNEL PROTEIN 3 (Fig. 1) (Bouain et al., 2019b). Additional candidate genes to regulate root growth under co-occurring Fe and $\mathrm{P}$ deficiency stress 
have been identified (AT1G51310; AT2G36200; AT4G09940; AT5G16580) and await functional validation (Bouain et al., 2019b). It is worth mentioning that a recent study showed, unexpectedly, that if Pi deficiency stimulates early root growth rate of most accessions, Fe deficiency reduces it (Bouain et al., 2019a). The combination of both Pi and Fe deficiency leads to a suppression of the growth inhibition exerted by Fe deficiency alone. Surprisingly, the Arabidopsis accession Columbia (Col-0) is not representative of the species under Pi deficiency (Bouain et al., 2019a), and therefore used inappropriately as reference for these stresses in the literature. Both discoveries go against the main stream of thinking and will have an impact on future research aiming at understanding plant response to nutrient deficiency. Finally, it is clear that Fe content plays not only a nutritional role in plants but also a central "signaling" role in controlling different aspects of plant growth under other nutrient deficiencies. For example, recent work has revealed a role for $\mathrm{Fe}$ in regulating the number of lateral roots in response to potassium deficiency via a complex mechanism involving auxin and changes in DNA methylation (Shahzad et al., 2020). In short, Arabidopsis roots exhibit increased numbers of lateral roots in response to this stress, and this response is dependent on the Fe status (Shahzad et al., 2020).

Once taken up by the roots, $\mathrm{Fe}$ can interact with $\mathrm{Pi}$, leading to a reduction in their translocation to the shoots (Cumbus et al., 1977; Mathan and Amberger, 1977). In shoots, these nutrients are stored in vacuoles or distributed among organelles such as the chloroplast. It is well known that photosynthesis is severely affected by either Fe or Pi deficiency (Chen and Barak, 1982; Carstensen et al., 2018). For instance, leaf Fe content correlates well with photosynthetic capacity (Terry and Abadia, 1986; Shikanai et al., 2003) and Fe deficiency causes chlorosis. Intriguingly, even if the leaf Fe level is sufficient, leaves with high Pi content still show chlorosis (Dekock et al., 1979). This provides further support for the interplay between Fe and Pi homeostasis in shoots. Remarkably, plants grown under a combined limitation of $\mathrm{Fe}$ and $\mathrm{Pi}$ do not show any chlorotic phenotype (Saenchai et al., 2016; Shi et al., 2018). Despite the importance of this phenomenon in agronomy, the characterization of $\mathrm{Fe}$ and $\mathrm{Pi}$ interactions involved in regulating photosynthesis is still in its infancy, and more research is needed to understand the complexity of how the various pathways involved are integrated. Systems genetic approaches can be used to screen for the phenotypic diversity of $\mathrm{Fe}$ and $\mathrm{Pi}$ stress responses across plant ecotypes and accessions, and would help to better understand how plants integrate nutrient deficiency signals to control photosynthesis (Rouached and Rhee, 2017). At the end of the plant life cycle, Fe is accumulated in the seed vacuoles, where it is mainly chelated and stored via its close interaction with Pi ions from phytate (Lanquar et al., 2005). Phytate content is one of the key factors in Fe remobilization during germination and seedling establishment. It has been shown that transgenic plants overexpressing 
bacterial phytase, an enzyme that degrades phytate, remobilize Fe faster during germination than wild type plants (Belgaroui et al., 2014). From a dietary point of view for humans, phytate is limiting $\mathrm{Fe}$, and also $\mathrm{Zn}$, absorption in the intestinal tract, therefore contributing to mineral deficiencies (Gibson et al., 2018). Finally, whereas it is known that Fe and Pi interact throughout the plant life cycle, our understanding of how this interaction, and the underlying molecular basis, varies between stages of plant growth and development remains limited.

\section{Conclusion and perspectives}

Fe deficiency or excess impacts plant metabolic functions, resulting in major physiological disorders that can adversely affect growth and development. We have discussed here that Fe homeostatic mechanisms are furthermore engaged in a wide range of interactions with other nutrients. The reductionist view of ion homeostasis regulation, in which each ion's level is controlled by its own mechanisms and signaling pathways, therefore needs to be revised (Bouain et al., 2019b). This is even more clear when we consider the mitigated success rate of research efforts focused on improving Fe content in plants (Shahzad et al., 2014). Investigating the precise molecular mechanisms coordinating Fe response pathways that shape plant developmental programs (i.e. root and shoot growth) in response to single or multiple nutrient deficiencies is topical. In this context, the existence of a tight coordination between the homeostasis of $\mathrm{Fe}$ and other mineral nutrients offers the potential to identify new mechanisms for Fe uptake and transport. A good example is the recent discovery of a new route for $\mathrm{Pi}$ transport and accumulation by the activation of a $\mathrm{Zn}$ deficiency signaling pathway (Bouain et al., 2014; Khan et al., 2014; Pal et al., 2017; Kisko et al., 2018). Similar to the effect of Zn deficiency on Pi accumulation, it has been shown that Fe accumulation strongly increases in response to combined nitrogen $(\mathrm{N})$ and Pi deficiencies, as compared to the small increase observed under either single Pi or $\mathrm{N}$ starvation stress (Kellermeier et al., 2014). Moreover, other micronutrient deficiencies ( $\mathrm{Zn}$ or $\mathrm{Mn}$ for instance) often cause increased Fe uptake (and vice versa), likely because micronutrients share transport and chelation systems with lax specificities, and mechanisms ensuring the tight coordination of micronutrient homeostasis are only starting to be uncovered. In addition to proteins involved in Fe uptake, transport, and storage, genetic manipulation of mechanisms recently shown to play a role in Fe dynamics in plants is of equal importance. For example, autophagy, i.e. the recycling of cytoplasmic components via encapsulation in vesicles and subsequent degradation in the vacuole (recently reviewed in Chen et al., 2019), influences Fe (and also $\mathrm{N}, \mathrm{Zn}, \mathrm{Mn}$ ) remobilization to seeds during leaf senescence (Pottier et al., 2014, 2019; Shinozaki et al., 2020). Hence, genetic inactivation of AuTophaGy 5 (ATG5) results in a $30 \%$ reduction of $\mathrm{Fe}$, as well as a $10-40 \%$ reduction of $\mathrm{N}$, in Arabidopsis seeds (Pottier et al., 
2019; Chen et al., 2019). Taken together, it is clear that designing research strategies to examine how Fe accumulation in plants is concomitantly influenced by the crosstalk of $\mathrm{N}, \mathrm{Pi}$ and other micronutrient signals will help identifying new players involved in Fe uptake and transport. Future research efforts need to focus on the molecular basis of the coordinated Fe, micro- and macronutrient homeostatic mechanisms, which will enable integrated approaches to improve $\mathrm{Fe}$ accumulation in crops. 


\section{Acknowledgements}

Research in the author's laboratories is funded by the "Fonds de la Recherche Scientifique-FNRS" (MIS-F.4511.16, CDR J.0009.17 and PDR-T0120.18 to MH), the University of Liège (ARC GreenMagic to $\mathrm{MH}$ ) and the "Agence Nationale de la Recherche (ANR)" (ANR-19-CE13-0007 to HR). The Michigan State University also supports HR. MH is Senior Research Associate of the F.R.S.-FNRS and SF was doctoral fellow of the FRIA.

\section{Author Contribution}

MH and HR conceptualized the manuscript. MH, HR, SE and SF wrote the draft manuscript. MH, HR and SF made the Figures. MH and HR reviewed and edited the manuscript. 


\section{References}

Agorio A, Giraudat J, Bianchi MW, Marion J, Espagne C, Castaings L, Lelièvre F, Curie C, Thomine S, Merlot S. 2017. Phosphatidylinositol 3-phosphate-binding protein AtPH1 controls the localization of the metal transporter NRAMP1 in Arabidopsis. Proceedings of the National Academy of Sciences 114, E3354-E3363.

Allen MD, del Campo JA, Kropat J, Merchant SS. 2007. FEA1, FEA2, and FRE1, encoding two homologous secreted proteins and a candidate ferrireductase, are expressed coordinately with FOX1 and FTR1 in iron-deficient Chlamydomonas reinhardtii. Eukaryotic Cell 6, 1841-1852.

Ariani A, Di Baccio D, Romeo S, Lombardi L, Andreucci A, Lux A, Horner DS, Sebastiani L. 2015. RNA sequencing of Populus $x$ canadensis roots identifies key molecular mechanisms underlying physiological adaption to excess zinc. PloS One 10, e0117571.

Arnold T, Kirk GJD, Wissuwa M, Frei M, Zhao F-J, Mason TFD, Weiss DJ. 2010. Evidence for the mechanisms of zinc uptake by rice using isotope fractionation. Plant, Cell \& Environment 33, 370-381.

Arrivault S, Senger T, Krämer U. 2006. The Arabidopsis metal tolerance protein AtMTP3 maintains metal homeostasis by mediating $\mathrm{Zn}$ exclusion from the shoot under Fe deficiency and Zn oversupply. The Plant Journal 46, 861-879.

Astolfi S, Zuchi S, Hubberten H-M, Pinton R, Hoefgen R. 2010. Supply of sulphur to S-deficient young barley seedlings restores their capability to cope with iron shortage. Journal of Experimental Botany 61 , 799-806.

Balzergue C, Dartevelle T, Godon C, et al. 2017. Low phosphate activates STOP1-ALMT1 to rapidly inhibit root cell elongation. Nature Communications 8, 15300.

Barberon M, Dubeaux G, Kolb C, Isono E, Zelazny E, Vert G. 2014. Polarization of IRON-REGULATED TRANSPORTER 1 (IRT1) to the plant-soil interface plays crucial role in metal homeostasis. Proceedings of the National Academy of Sciences of the United States of America 111, 8293-8298.

Barberon M, Zelazny E, Robert S, Conéjéro G, Curie C, Friml J, Vert G. 2011. Monoubiquitin-dependent endocytosis of the iron-regulated transporter 1 (IRT1) transporter controls iron uptake in plants. Proceedings of the National Academy of Sciences of the United States of America 108, E450-8.

Bashir K, Takahashi R, Nakanishi H, Nishizawa NK. 2013. The road to micronutrient biofortification of rice: progress and prospects. Frontiers in Plant Science 4, 15.

Baxter IR, Vitek O, Lahner B, Muthukumar B, Borghi M, Morrissey J, Guerinot ML, Salt DE. 2008. The leaf ionome as a multivariable system to detect a plant's physiological status. Proceedings of the National Academy of Sciences 105, 12081-12086.

Belgaroui N, Zaidi I, Farhat A, et al. 2014. Over-expression of the bacterial phytase US417 in Arabidopsis reduces the concentration of phytic acid and reveals its involvement in the regulation of sulfate and phosphate homeostasis and signaling. Plant \& Cell Physiology 55, 1912-1924.

Beneš I, Schreiber K, Ripperger H, Kircheiss A. 1983. Metal complex formation by nicotianamine, a 
possible phytosiderophore. Experientia 39, 261-262.

Benitez-Nelson CR. 2000. The biogeochemical cycling of phosphorus in marine systems. Earth-Science Reviews 51, 109-135.

Bian B, Kageshima S, Yano K, Fujiwara T, Kamiya T. 2018. Screening Arabidopsis thaliana mutants for low sensitivity to manganese identifies novel alleles of NRAMP1 and PGSIP6. Journal of Experimental Botany 69, 1795-1803.

Blaby-Haas CE, Merchant SS. 2012. The ins and outs of algal metal transport. Biochimica Biophysica Acta 1823, 1531-1552.

Blaby-Haas CE, Merchant SS. 2014. Lysosome-related organelles as mediators of metal homeostasis. The Journal of Biological Chemistry 289, 28129-28136.

Blaby-Haas CE, Merchant SS. 2017. Regulating cellular trace metal economy in algae. Current Opinion in Plant Biology 39, 88-96.

Bouain N, Korte A, Satbhai SB, Nam H-I, Rhee SY, Busch W, Rouached H. 2019a. Systems genomics approaches provide new insights into Arabidopsis thaliana root growth regulation under combinatorial mineral nutrient limitation. PLoS Genetics 15, e1008392.

Bouain N, Krouk G, Lacombe B, Rouached H. 2019b. Getting to the Root of Plant Mineral Nutrition: Combinatorial Nutrient Stresses Reveal Emergent Properties. Trends in Plant Science 24, 542-552.

Bouain N, Shahzad Z, Rouached A, Khan GA, Berthomieu P, Abdelly C, Poirier Y, Rouached H. 2014. Phosphate and zinc transport and signalling in plants: toward a better understanding of their homeostasis interaction. Journal of Experimental Botany 65, 5725-5741.

Bournier M, Tissot N, Mari S, Boucherez J, Lacombe E, Briat J-F, Gaymard F. 2013. Arabidopsis ferritin 1 (AtFer1) gene regulation by the phosphate starvation response 1 (AtPHR1) transcription factor reveals a direct molecular link between iron and phosphate homeostasis. The Journal of Biological Chemistry 288, 22670-22680.

Boyd ES, Peters JW. 2013. New insights into the evolutionary history of biological nitrogen fixation. Frontiers in Microbiology 4, 201.

Boyd PW, Jickells T, Law CS, Blain S, Boyle EA, Buesseler KO, Coale KH, Cullen JJ, de Baar HJW, Follows M, Harvey M, Lancelot C, Levasseur M, Owens NPJ, Pollard R, Rivkin RB, Sarmiento J, Schoemann V, Smetacek V, Takeda S, Tsuda A, Turner S, Watson AJ. 2007. Mesoscale Iron Enrichment Experiments 1993-2005: Synthesis and Future Directions. Science 315, 612-617.

Briat J-F, Dubos C, Gaymard F. 2015a. Iron nutrition, biomass production, and plant product quality. Trends in Plant Science 20, 33-40.

Briat J-F, Gojon A, Plassard C, Rouached H, Lemaire G. 2020. Reappraisal of the central role of soil nutrient availability in nutrient management in light of recent advances in plant nutrition at crop and molecular levels. European Journal of Agronomy 116, 126069. 
Briat J-F, Rouached H, Tissot N, Gaymard F, Dubos C. 2015b. Integration of P, S, Fe, and Zn nutrition signals in Arabidopsis thaliana: potential involvement of PHOSPHATE STARVATION RESPONSE 1 (PHR1). Frontiers in Plant Science 6, 290.

Broadley MR, White PJ, Hammond JP, Zelko I, Lux A. 2007. Zinc in plants. New Phytologist 173, 677702.

Brodie J, Chan CX, De Clerck O, et al. 2017. The Algal Revolution. Trends in Plant Science 22, 726-738.

Brumbarova T, Bauer P, Ivanov R. 2015. Molecular mechanisms governing Arabidopsis iron uptake. Trends in Plant Science 20, 124-133.

Buet A, Simontacchi M. 2015. Nitric oxide and plant iron homeostasis. Annals of the New York Academy of Sciences 1340, 39-46.

Cailliatte R, Schikora A, Briat J-F, Mari S, Curie C. 2010. High-affinity manganese uptake by the metal transporter NRAMP1 is essential for Arabidopsis growth in low manganese conditions. The Plant Cell 22, 904-917.

Campos ACAL, Kruijer W, Alexander R, Akkers RC, Danku J, Salt DE, Aarts MGM. 2017. Natural variation in Arabidopsis thaliana reveals shoot ionome, biomass, and gene expression changes as biomarkers for zinc deficiency tolerance. Journal of Experimental Botany 68, 3643-3656.

Cardol P, Bailleul B, Rappaport F, et al. 2008. An original adaptation of photosynthesis in the marine green alga Ostreococcus. Proceedings of the National Academy of Sciences of the United States of America 105, 7881-7886.

Carrió-Seguí À, Ruiz-Rivero O, Villamayor-Belinchón L, Puig S, Perea-García A, Peñarrubia L. 2019. The Altered Expression of microRNA408 Influences the Arabidopsis Response to Iron Deficiency. Frontiers in Plant Science 10.

Carstensen A, Herdean A, Schmidt SB, Sharma A, Spetea C, Pribil M, Husted S. 2018. The Impacts of Phosphorus Deficiency on the Photosynthetic Electron Transport Chain. Plant Physiology 177, 271-284.

Cassin G, Mari S, Curie C, Briat J-F, Czernic P. 2009. Increased sensitivity to iron deficiency in Arabidopsis thaliana overaccumulating nicotianamine. Journal of Experimental Botany 60, 1249-1259.

Castaings L, Caquot A, Loubet S, Curie C. 2016. The high-affinity metal Transporters NRAMP1 and IRT1 Team up to Take up Iron under Sufficient Metal Provision. Scientific Reports 6, 37222.

Chaney RL. 1993. Zinc Phytotoxicity. Zinc in Soils and Plants, 135-150.

Charlier J-B, Polese C, Nouet C, Carnol M, Bosman B, Krämer U, Motte P, Hanikenne M. 2015. Zinc triggers a complex transcriptional and post-transcriptional regulation of the metal homeostasis gene FRD3 in Arabidopsis relatives. Journal of Experimental Botany 66, 3865-3878.

Chen Y, Barak P. 1982. Iron Nutrition of Plants in Calcareous Soils. In: Brady NC, ed. Advances in Agronomy. Academic Press, 217-240. 
Chen C-L, Cui Y, Cui M, Zhou W-J, Wu H-L, Ling H-Q. 2018. A FIT-binding protein is involved in modulating iron and zinc homeostasis in Arabidopsis. Plant, Cell \& Environment 41, 1698-1714.

Chen X, Tian D, Kong X, Chen Q, E.F AA, Hu X, Jia A. 2016. The role of nitric oxide signalling in response to salt stress in Chlamydomonas reinhardtii. Planta 244, 651-669.

Cheng L, Wang F, Shou H, et al. 2007. Mutation in nicotianamine aminotransferase stimulated the Fe(II) acquisition system and led to iron accumulation in rice. Plant Physiology 145, 1647-1657.

Chen Q, Shinozaki D, Luo J, et al. 2019. Autophagy and Nutrients Management in Plants. Cells 8, 1426.

Chu H-H, Chiecko J, Punshon T, Lanzirotti A, Lahner B, Salt DE, Walker EL. 2010. Successful reproduction requires the function of Arabidopsis Yellow Stripe-Like1 and Yellow Stripe-Like3 metalnicotianamine transporters in both vegetative and reproductive structures. Plant Physiology 154, 197210.

Ciaffi M, Paolacci AR, Celletti S, Catarcione G, Kopriva S, Astolfi S. 2013. Transcriptional and physiological changes in the $S$ assimilation pathway due to single or combined $S$ and Fe deprivation in durum wheat (Triticum durum L.) seedlings. Journal of Experimental Botany 64, 1663-1675.

Clemens S. 2019. Metal ligands in micronutrient acquisition and homeostasis. Plant, Cell \& Environment 42, 2902-2912.

Colangelo EP, Guerinot ML. 2004. The essential basic helix-loop-helix protein FIT1 is required for the iron deficiency response. The Plant Cell 16, 3400-3412.

Connolly EL, Fett JP, Guerinot ML. 2002. Expression of the IRT1 metal transporter is controlled by metals at the levels of transcript and protein accumulation. The Plant Cell 14, 1347-1357.

Conte SS, Chu HH, Rodriguez DC, Punshon T, Vasques KA, Salt DE, Walker EL. 2013. Arabidopsis thaliana Yellow Stripe1-Like4 and Yellow Stripe1-Like6 localize to internal cellular membranes and are involved in metal ion homeostasis. Frontiers in Plant Science 4, 283.

Cornu J-Y, Deinlein U, Höreth S, Braun M, Schmidt H, Weber M, Persson DP, Husted S, Schjoerring JK, Clemens S. 2015. Contrasting effects of nicotianamine synthase knockdown on zinc and nickel tolerance and accumulation in the zinc/cadmium hyperaccumulator Arabidopsis halleri. New Phytologist 206, 738750.

Corso M, Schvartzman MS, Guzzo F, Souard F, Malkowski E, Hanikenne M, Verbruggen N. 2018. Contrasting cadmium resistance strategies in two metallicolous populations of Arabidopsis halleri. New Phytologist 218, 283-297.

Couturier J, Touraine B, Briat J-F, Gaymard F, Rouhier N. 2013. The iron-sulfur cluster assembly machineries in plants: current knowledge and open questions. Frontiers in Plant Science 4, 259.

Cumbus IP, Hornsey DJ, Robinson LW. 1977. The influence of phosphorus, zinc and manganese on absorption and translocation of iron in watercress. Plant and Soil 48, 651-660.

Curie C, Alonso JM, Le Jean M, Ecker JR, Briat JF. 2000. Involvement of NRAMP1 from Arabidopsis 
thaliana in iron transport. Biochemical Journal 347 Pt 3, 749-755.

Curie C, Panaviene Z, Loulergue C, Dellaporta SL, Briat JF, Walker EL. 2001. Maize yellow stripe1 encodes a membrane protein directly involved in Fe(III) uptake. Nature 409, 346-349.

De Clerck O, Kao S-M, Bogaert KA, et al. 2018. Insights into the Evolution of Multicellularity from the Sea Lettuce Genome. Current Biology 28, 2921-2933.e5.

Deinlein U, Weber M, Schmidt H, et al. 2012. Elevated nicotianamine levels in Arabidopsis halleri roots play a key role in zinc hyperaccumulation. The Plant Cell 24, 708-723.

Dekock PC, Hall A, Inkson RHE. 1979. Active Iron in Plant Leaves. Annals of Botany 43, 737-740.

Delhaize E. 1996. A metal-accumulator mutant of Arabidopsis thaliana. Plant Physiology 111, 849-855.

DiDonato RJ Jr, Roberts LA, Sanderson T, Eisley RB, Walker EL. 2004. Arabidopsis Yellow Stripe-Like2 (YSL2): a metal-regulated gene encoding a plasma membrane transporter of nicotianamine-metal complexes. The Plant Journal 39, 403-414.

Docampo R, de Souza W, Miranda K, Rohloff P, Moreno SNJ. 2005. Acidocalcisomes ? conserved from bacteria to man. Nature Reviews Microbiology 3, 251-261.

Dubeaux G, Neveu J, Zelazny E, Vert G. 2018. Metal Sensing by the IRT1 Transporter-Receptor Orchestrates Its Own Degradation and Plant Metal Nutrition. Molecular Cell 69, 953-964.e5.

Dubeaux G, Zelazny E, Vert G. 2015. Getting to the root of plant iron uptake and cell-cell transport: Polarity matters! Communicative \& Integrative Biology 8, e1038441.

Durrett TP, Gassmann W, Rogers EE. 2007. The FRD3-mediated efflux of citrate into the root vasculature is necessary for efficient iron translocation. Plant Physiology 144, 197-205.

Eide D, Broderius M, Fett J, Guerinot ML. 1996. A novel iron-regulated metal transporter from plants identified by functional expression in yeast. Proceedings of the National Academy of Sciences of the United States of America 93, 5624-5628.

Eroglu S, Meier B, von Wirén N, Peiter E. 2016. The Vacuolar Manganese Transporter MTP8 Determines Tolerance to Iron Deficiency-Induced Chlorosis in Arabidopsis. Plant Physiology 170, 1030-1045.

Escudero V, Abreu I, Tejada-Jiménez M, et al. 2020. Medicago truncatula Ferroportin2 mediates iron import into nodule symbiosomes. New Phytologist doi: 10.1111/nph.16642.

Evens NP, Buchner P, Williams LE, Hawkesford MJ. 2017. The role of ZIP transporters and group F bZIP transcription factors in the $\mathrm{Zn}$-deficiency response of wheat (Triticum aestivum). The Plant Journal 92, 291-304.

Falciatore A, d'Alcalà MR, Croot P, Bowler C. 2000. Perception of environmental signals by a marine diatom. Science 288, 2363-2366.

Flis P, Ouerdane L, Grillet L, Curie C, Mari S, Lobinski R. 2016. Inventory of metal complexes circulating 
in plant fluids: a reliable method based on HPLC coupled with dual elemental and high-resolution molecular mass spectrometric detection. New Phytologist 211, 1129-1141.

Forieri I, Wirtz M, Hell R. 2013. Toward new perspectives on the interaction of iron and sulfur metabolism in plants. Frontiers in Plant Science 4.

Foy CD, Chaney RL, White MC. 1978. The Physiology of Metal Toxicity in Plants. Annual Review of Plant Physiology 29, 511-566.

Fukao Y, Ferjani A, Tomioka R, Nagasaki N, Kurata R, Nishimori Y, Fujiwara M, Maeshima M. 2011. iTRAQ analysis reveals mechanisms of growth defects due to excess zinc in Arabidopsis. Plant Physiology 155, 1893-1907.

Gibson RS, Raboy V, King JC. 2018. Implications of phytate in plant-based foods for iron and zinc bioavailability, setting dietary requirements, and formulating programs and policies. Nutrition Reviews 76, 793-804.

González-Guerrero M, Matthiadis A, Sáez Á, Long TA. 2014. Fixating on metals: new insights into the role of metals in nodulation and symbiotic nitrogen fixation. Frontiers in Plant Science 5, 45.

Green LS, Rogers EE. 2004. FRD3 controls iron localization in Arabidopsis. Plant Physiology 136, 25232531.

Grillet L, Schmidt W. 2019. Iron acquisition strategies in land plants: not so different after all. New Phytologist 224, 11-18.

Gruber BD, Giehl RFH, Friedel S, von Wirén N. 2013. Plasticity of the Arabidopsis root system under nutrient deficiencies. Plant Physiology 163, 161-179.

Halimaa P, Blande D, Aarts MGM, Tuomainen M, Tervahauta A, Kärenlampi S. 2014a. Comparative transcriptome analysis of the metal hyperaccumulator Noccaea caerulescens. Frontiers in Plant Science 5, 213.

Halimaa P, Blande D, Baltzi E, et al. 2019. Transcriptional effects of cadmium on iron homeostasis differ in calamine accessions of Noccaea caerulescens. The Plant Journal 97, 306-320.

Halimaa P, Lin Y-F, Ahonen VH, et al. 2014b. Gene expression differences between Noccaea caerulescens ecotypes help to identify candidate genes for metal phytoremediation. Environmental Science \& Technology 48, 3344-3353.

Hanikenne M, Bernal M, Urzica E-I. 2014. Ion homeostasis in the Chloroplast. Plastid Biology, 465-514.

Hanikenne M, Krämer U, Demoulin V, Baurain D. 2005a. A comparative inventory of metal transporters in the green alga Chlamydomonas reinhardtii and the red alga Cyanidioschizon merolae. Plant Physiology 137, 428-446.

Hanikenne M, Merchant SS, Hamel P. 2009. Transition Metal Nutrition. The Chlamydomonas Sourcebook, 333-399. 
Hanikenne M, Motte P, Wu MCS, Wang T, Loppes R, Matagne RF. 2005b. A mitochondrial half-size ABC transporter is involved in cadmium tolerance in Chlamydomonas reinhardtii. Plant Cell \& Environment 28, 863-873.

Hanikenne M, Nouet C. 2011. Metal hyperaccumulation and hypertolerance: a model for plant evolutionary genomics. Current Opinion in Plant Biology 14, 252-259.

Haydon MJ, Cobbett CS. 2007a. Transporters of ligands for essential metal ions in plants. New Phytologist 174, 499-506.

Haydon MJ, Cobbett CS. 2007b. A novel major facilitator superfamily protein at the tonoplast influences zinc tolerance and accumulation in Arabidopsis. Plant Physiology 143, 1705-1719.

Haydon MJ, Kawachi M, Wirtz M, Hillmer S, Hell R, Krämer U. 2012. Vacuolar nicotianamine has critical and distinct roles under iron deficiency and for zinc sequestration in Arabidopsis. The Plant Cell 24, 724737.

Herbik A, Bölling C, Buckhout TJ. 2002. The involvement of a multicopper oxidase in iron uptake by the green algae Chlamydomonas reinhardtii. Plant Physiology 130, 2039-2048.

Hirsch J, Marin E, Floriani M, Chiarenza S, Richaud P, Nussaume L, Thibaud MC. 2006. Phosphate deficiency promotes modification of iron distribution in Arabidopsis plants. Biochimie 88, 1767-1771.

Hopkinson BM, Morel FMM. 2009. The role of siderophores in iron acquisition by photosynthetic marine microorganisms. Biometals 22, 659-669.

Howe CJ, Schlarb-Ridley BG, Wastl J, Purton S, Bendall DS. 2006. The novel cytochrome c6 of chloroplasts: a case of evolutionary bricolage? Journal of Experimental Botany 57, 13-22.

Inoue H, Kobayashi T, Nozoye T, Takahashi M, Kakei Y, Suzuki K, Nakazono M, Nakanishi H, Mori S, Nishizawa NK. 2009. Rice OsYSL15 is an iron-regulated iron ${ }^{(I I I)}$-deoxymugineic acid transporter expressed in the roots and is essential for iron uptake in early growth of the seedlings. The Journal of Biological Chemistry 284, 3470-3479.

Inoue H, Mizuno D, Takahashi M, Nakanishi H, Mori S, Nishizawa NK. 2004. A rice FRD3-like (OsFRDL1) gene is expressed in the cells involved in long-distance transport. Soil Science and Plant Nutrition 50, 1133-1140.

Ishimaru Y, Kakei Y, Shimo H, Bashir K, Sato Y, Sato Y, Uozumi N, Nakanishi H, Nishizawa NK. 2011. A rice phenolic efflux transporter is essential for solubilizing precipitated apoplasmic iron in the plant stele. The Journal of Biological Chemistry 286, 24649-24655.

Ishimaru Y, Suzuki M, Ogo Y, Takahashi M, Nakanishi H, Mori S, Nishizawa NK. 2008. Synthesis of nicotianamine and deoxymugineic acid is regulated by OsIRO2 in $\mathrm{Zn}$ excess rice plants. Soil Science and Plant Nutrition 54, 417-423.

Ishimaru Y, Suzuki M, Tsukamoto T, et al. 2006. Rice plants take up iron as an $\mathrm{Fe}^{3+}$-phytosiderophore and as $\mathrm{Fe}^{2+}$. The Plant Journal 45, 335-346. 
Karam M-J, Souleman D, Schvartzman MS, Gallina S, Spielmann J, Poncet C, Bouchez O, Pauwels M, Hanikenne M, Frérot H. 2019. Genetic architecture of a plant adaptive trait: QTL mapping of intraspecific variation for tolerance to metal pollution in Arabidopsis halleri. Heredity 122, 877-892.

Kaur G, Shukla V, Kumar A, et al. 2019. Integrative analysis of hexaploid wheat roots identifies signature components during iron starvation. Journal of Experimental Botany 70, 6141-6161.

Keeling PJ. 2013. The number, speed, and impact of plastid endosymbioses in eukaryotic evolution. Annual Review of Plant Biology 64, 583-607.

Kellermeier F, Armengaud P, Seditas TJ, Danku J, Salt DE, Amtmann A. 2014. Analysis of the Root System Architecture of Arabidopsis Provides a Quantitative Readout of Crosstalk between Nutritional Signals. The Plant Cell 26, 1480-1496.

Khan GA, Bouraine S, Wege S, Li Y, de Carbonnel M, Berthomieu P, Poirier Y, Rouached H. 2014. Coordination between zinc and phosphate homeostasis involves the transcription factor PHR1, the phosphate exporter PHO1, and its homologue PHO1; H3 in Arabidopsis. Journal of Experimental Botany 65, 871-884.

Kim DY, Bovet L, Kushnir S, Noh EW, Martinoia E, Lee Y. 2006. AtATM3 is involved in heavy metal resistance in Arabidopsis. Plant Physiology 140, 922-932.

Kim SA, Punshon T, Lanzirotti A, Li L, Alonso JM, Ecker JR, Kaplan J, Guerinot ML. 2006. Localization of iron in Arabidopsis seed requires the vacuolar membrane transporter VIT1. Science 314, 1295-1298.

Kim S, Takahashi M, Higuchi K, Tsunoda K, Nakanishi H, Yoshimura E, Mori S, Nishizawa NK. 2005. Increased nicotianamine biosynthesis confers enhanced tolerance of high levels of metals, in particular nickel, to plants. Plant \& Cell Physiology 46, 1809-1818.

Kisko M, Bouain N, Safi A, et al. 2018. LPCAT1 controls phosphate homeostasis in a zinc-dependent manner. eLife 7, e32077.

Klatte M, Schuler M, Wirtz M, Fink-Straube C, Hell R, Bauer P. 2009. The analysis of Arabidopsis nicotianamine synthase mutants reveals functions for nicotianamine in seed iron loading and iron deficiency responses. Plant Physiology 150, 257-271.

Kobayashi T, Nishizawa NK. 2012. Iron Uptake, Translocation, and Regulation in Higher Plants. Annual Review of Plant Biology 63, 131-152.

Kobayashi T, Nishizawa NK. 2015. Intracellular iron sensing by the direct binding of iron to regulators. Frontiers in Plant Science 6, 155.

Kobayashi T, Nozoye T, Nishizawa NK. 2019. Iron transport and its regulation in plants. Free Radical Biology and Medicine 133, 11-20.

Krämer U. 2010. Metal hyperaccumulation in plants. Annual Review of Plant Biology 61, 517-534.

Krämer U, Talke IN, Hanikenne M. 2007. Transition metal transport. FEBS Letters 581, 2263-2272. 
La Fontaine S, Quinn JM, Nakamoto SS, Page MD, Göhre V, Moseley JL, Kropat J, Merchant S. 2002. Copper-dependent iron assimilation pathway in the model photosynthetic eukaryote Chlamydomonas reinhardtii. Eukaryotic Cell 1, 736-757.

Lanquar V, Lelièvre F, Bolte $\mathbf{S}$, et al. 2005. Mobilization of vacuolar iron by AtNRAMP3 and AtNRAMP4 is essential for seed germination on low iron. EMBO Journal 24, 4041-4051.

Lanquar V, Ramos MS, Lelièvre F, Barbier-Brygoo H, Krieger-Liszkay A, Krämer U, Thomine S. 2010. Export of vacuolar manganese by AtNRAMP3 and AtNRAMP4 is required for optimal photosynthesis and growth under manganese deficiency. Plant Physiology 152, 1986-1999.

Lee S, An G. 2009. Over-expression of OsIRT1 leads to increased iron and zinc accumulations in rice. Plant, Cell \& Environment 32, 408-416.

Le Jean M, Schikora A, Mari S, Briat J-F, Curie C. 2005. A loss-of-function mutation in AtYSL1 reveals its role in iron and nicotianamine seed loading. The Plant Journal 44, 769-782.

Lelandais G, Scheiber I, Paz-Yepes J, et al. 2016. Ostreococcus tauri is a new model green alga for studying iron metabolism in eukaryotic phytoplankton. BMC Genomics 17, 319.

Lešková A, Giehl RFH, Hartmann A, Fargašová A, von Wirén N. 2017. Heavy Metals Induce Iron Deficiency Responses at Different Hierarchic and Regulatory Levels. Plant Physiology 174, 1648-1668.

Li J, Liu B, Cheng F, Wang X, Aarts MGM, Wu J. 2014. Expression profiling reveals functionally redundant multiple-copy genes related to zinc, iron and cadmium responses in Brassica rapa. New Phytologist 203, 182-194.

Lin Y-F, Liang H-M, Yang S-Y, Boch A, Clemens S, Chen C-C, Wu J-F, Huang J-L, Yeh K-C. 2009. Arabidopsis IRT3 is a zinc-regulated and plasma membrane localized zinc/iron transporter. New Phytologist 182, 392-404.

Li B, Sun L, Huang J, Göschl C, Shi W, Chory J, Busch W. 2019. GSNOR provides plant tolerance to iron toxicity via preventing iron-dependent nitrosative and oxidative cytotoxicity. Nature Communications 10, 3896.

Liu J, Tan K, He L, Qiu Y, Tan W, Guo Y, Wang Z, Sun W. 2018. Effect of limitation of iron and manganese on microalgae growth in fresh water. Microbiology 164, 1514-1521.

Li S, Zhou X, Chen J, Chen R. 2018. Is there a strategy I iron uptake mechanism in maize? Plant Signaling \& Behavior 13, e1161877.

Li S, Zhou X, Huang Y, Zhu L, Zhang S, Zhao Y, Guo J, Chen J, Chen R. 2013. Identification and characterization of the zinc-regulated transporters, iron-regulated transporter-like protein (ZIP) gene family in maize. BMC Plant Biology 13, 114.

López-Millán AF, Morales F, Abadía A, Abadía J. 2000. Effects of iron deficiency on the composition of the leaf apoplastic fluid and xylem sap in sugar beet. Implications for iron and carbon transport. Plant Physiology 124, 873-884. 
Maldonado MT, Allen AE, Chong JS, Lin K, Leus D, Karpenko N, Harris SL. 2006. Copper-dependent iron transport in coastal and oceanic diatoms. Limnology and Oceanography 51, 1729-1743.

Marković T, Manzoor S, Humphreys-Williams E, Kirk GJ, Vilar R, Weiss DJ. 2017. Experimental Determination of Zinc Isotope Fractionation in Complexes with the Phytosiderophore 2' -Deoxymugeneic Acid (DMA) and Its Structural Analogues, and Implications for Plant Uptake Mechanisms. Environmental Science \& Technology 51, 98-107.

Marschner H. 2012. Marschner's Mineral Nutrition of Higher Plants. Academic Press.

Marschner H, Römheld V. 1994. Strategies of plants for acquisition of iron. Plant and Soil 165, 261-274.

Mathan KK, Amberger A. 1977. Influence of iron on the uptake of phosphorus by maize. Plant and Soil 46, 413-422.

Meier SK, Adams N, Wolf M, Balkwill K, Muasya AM, Gehring CA, Bishop JM, Ingle RA. 2018. Comparative RNA-seq analysis of nickel hyperaccumulating and non-accumulating populations of Senecio coronatus (Asteraceae). The Plant Journal 95, 1023-1038.

Merchant SS. 2007. Trace Metal Utilization in Chloroplasts. Advances in Photosynthesis and Respiration, 199-218.

Merchant SS, Allen MD, Kropat J, Moseley JL, Long JC, Tottey S, Terauchi AM. 2006. Between a rock and a hard place: trace element nutrition in Chlamydomonas. Biochimica et Biophysica Acta 1763, 578594.

Merlot S, de la Torre VSG, Hanikenne M. 2018. Physiology and Molecular Biology of Trace Element Hyperaccumulation. Agromining: Farming for Metals, 93-116.

Milner MJ, Mitani-Ueno N, Yamaji N, Yokosho K, Craft E, Fei Z, Ebbs S, Clemencia Zambrano M, Ma JF, Kochian LV. 2014. Root and shoot transcriptome analysis of two ecotypes of Noccaea caerulescens uncovers the role of NcNramp1 in Cd hyperaccumulation. The Plant Journal 78, 398-410.

Misson J, Raghothama KG, Jain A, et al. 2005. A genome-wide transcriptional analysis using Arabidopsis thaliana Affymetrix gene chips determined plant responses to phosphate deprivation. Proceedings of the National Academy of Sciences 102, 11934-11939.

Molins H, Michelet L, Lanquar V, Agorio A, Giraudat J, Roach T, Krieger-Liszkay A, Thomine S. 2013. Mutants impaired in vacuolar metal mobilization identify chloroplasts as a target for cadmium hypersensitivity in Arabidopsis thaliana. Plant, Cell \& environment 36, 804-817.

Mora-Macías J, Ojeda-Rivera JO, Gutiérrez-Alanís D, Yong-Villalobos L, Oropeza-Aburto A, RayaGonzález J, Jiménez-Domínguez G, Chávez-Calvillo G, Rellán-Álvarez R, Herrera-Estrella L. 2017. Malate-dependent Fe accumulation is a critical checkpoint in the root developmental response to low phosphate. Proceedings of the National Academy of Sciences of the United States of America 114, E3563-E3572.

Morel M, Crouzet J, Gravot A, Auroy P, Leonhardt N, Vavasseur A, Richaud P. 2009. AtHMA3, a P1BATPase allowing Cd/Zn/Co/Pb vacuolar storage in Arabidopsis. Plant Physiology 149, 894-904. 
Morrissey J, Baxter IR, Lee J, Li L, Lahner B, Grotz N, Kaplan J, Salt DE, Guerinot ML. 2009. The ferroportin metal efflux proteins function in iron and cobalt homeostasis in Arabidopsis. The Plant Cell 21, 3326-3338.

Morrissey J, Bowler C. 2012. Iron Utilization in Marine Cyanobacteria and Eukaryotic Algae. Frontiers in Microbiology 3.

Morrissey J, Guerinot ML. 2009. Iron uptake and transport in plants: the good, the bad, and the ionome. Chemical Reviews 109, 4553-4567.

Morrissey J, Sutak R, Paz-Yepes J, et al. 2015. A novel protein, ubiquitous in marine phytoplankton, concentrates iron at the cell surface and facilitates uptake. Current Biology 25, 364-371.

van de Mortel JE, Almar Villanueva L, Schat H, Kwekkeboom J, Coughlan S, Moerland PD, Ver Loren van Themaat E, Koornneef M, Aarts MGM. 2006. Large expression differences in genes for iron and zinc homeostasis, stress response, and lignin biosynthesis distinguish roots of Arabidopsis thaliana and the related metal hyperaccumulator Thlaspi caerulescens. Plant Physiology 142, 1127-1147.

Moseley JL, Chang C-W, Grossman AR. 2006. Genome-based approaches to understanding phosphorus deprivation responses and PSR1 control in Chlamydomonas reinhardtii. Eukaryotic Cell 5, 26-44.

Müller R, Morant M, Jarmer H, Nilsson L, Nielsen TH. 2007. Genome-wide analysis of the Arabidopsis leaf transcriptome reveals interaction of phosphate and sugar metabolism. Plant Physiology 143, 156171.

Mus F, Crook MB, Garcia K, et al. 2016. Symbiotic Nitrogen Fixation and the Challenges to Its Extension to Nonlegumes. Applied and Environmental Microbiology 82, 3698-3710.

Nakanishi H, Ogawa I, Ishimaru Y, Mori S, Nishizawa NK. 2006. Iron deficiency enhances cadmium uptake and translocation mediated by the $\mathrm{Fe}^{2+}$ transporters OsIRT1 and OsIRT2 in rice. Soil Science and Plant Nutrition 52, 464-469.

Nishida S, Tsuzuki C, Kato A, Aisu A, Yoshida J, Mizuno T. 2011. AtIRT1, the primary iron uptake transporter in the root, mediates excess nickel accumulation in Arabidopsis thaliana. Plant \& Cell Physiology 52, 1433-1442.

Nouet C, Motte P, Hanikenne M. 2011. Chloroplastic and mitochondrial metal homeostasis. Trends in Plant Science 16, 395-404.

Nozoye T, Nagasaka S, Kobayashi T, Sato Y, Uozumi N, Nakanishi H, Nishizawa NK. 2015. The Phytosiderophore Efflux Transporter TOM2 Is Involved in Metal Transport in Rice. The Journal of Biological Chemistry 290, 27688-27699.

Nozoye T, Nagasaka S, Kobayashi T, Takahashi M, Sato Y, Sato Y, Uozumi N, Nakanishi H, Nishizawa NK. 2011. Phytosiderophore efflux transporters are crucial for iron acquisition in graminaceous plants. The Journal of Biological Chemistry 286, 5446-5454.

Nozoye T, von Wirén N, Sato Y, Higashiyama T, Nakanishi H, Nishizawa NK. 2019. Characterization of the Nicotianamine Exporter ENA1 in Rice. Frontiers in Plant Science 10, 502. 
Oomen RJFJ, Wu J, Lelièvre F, Blanchet S, Richaud P, Barbier-Brygoo H, Aarts MGM, Thomine S. 2009. Functional characterization of NRAMP3 and NRAMP4 from the metal hyperaccumulator Thlaspi caerulescens. New Phytologist 181, 637-650.

Pal S, Kisko M, Dubos C, Lacombe B, Berthomieu P, Krouk G, Rouached H. 2017. TransDetect Identifies a New Regulatory Module Controlling Phosphate Accumulation. Plant Physiology 175, 916-926.

Paolacci AR, Celletti S, Catarcione G, Hawkesford MJ, Astolfi S, Ciaffi M. 2014. Iron deprivation results in a rapid but not sustained increase of the expression of genes involved in iron metabolism and sulfate uptake in tomato (Solanum lycopersicum L.) seedlings. Journal of Integrative Plant Biology 56, 88-100.

Paz Y, Katz A, Pick U. 2007. A multicopper ferroxidase involved in iron binding to transferrins in Dunaliella salina plasma membranes. The Journal of Biological Chemistry 282, 8658-8666.

Pedas P, Ytting CK, Fuglsang AT, Jahn TP, Schjoerring JK, Husted S. 2008. Manganese efficiency in barley: identification and characterization of the metal ion transporter HVIRT1. Plant Physiology 148, 455-466.

Penen F, Isaure MP, Dobritzsch D, Bertalan I, Castillo-Michel H, Proux O, Gontier E, Le Coustumer P, Schaumlöffel D. 2017. Pools of cadmium in Chlamydomonas reinhardtii revealed by chemical imaging and XAS spectroscopy. Metallomics 9, 910-923.

Pianelli K, Mari S, Marquès L, Lebrun M, Czernic P. 2005. Nicotianamine over-accumulation confers resistance to nickel in Arabidopsis thaliana. Transgenic Research 14, 739-748.

Pilon M. 2017. The copper microRNAs. New Phytologist 213, 1030-1035.

Pineau C, Loubet S, Lefoulon C, Chalies C, Fizames C, Lacombe B, Ferrand M, Loudet O, Berthomieu P, Richard 0. 2012. Natural variation at the FRD3 MATE transporter locus reveals cross-talk between Fe homeostasis and Zn tolerance in Arabidopsis thaliana. PLoS Genetics 8, e1003120.

Pottier M, Dumont J, Masclaux-Daubresse C, Thomine S. 2019. Autophagy is essential for optimal translocation of iron to seeds in Arabidopsis. Journal of Experimental Botany 70, 859-869.

Pottier M, Masclaux-Daubresse C, Yoshimoto K, Thomine S. 2014. Autophagy as a possible mechanism for micronutrient remobilization from leaves to seeds. Frontiers in Plant Science 5, 11.

Prasanna R, Kaushik BD. 2010. Evolutionary relationships among cyanobacteria, algae and plants: Revisited in the light of Darwinism. Nature at Work: Ongoing Saga of Evolution, 119-140.

Ptashnyk M, Roose T, Jones DL, Kirk GJD. 2011. Enhanced zinc uptake by rice through phytosiderophore secretion: a modelling study. Plant, Cell \& Environment 34, 2038-2046.

Qiu Y, Wang Z, Liu F, Wu Z, Chen H, Tang D, Liu J. 2020. Effect of complex iron on the phosphorus absorption by two freshwater algae. Environmental Technology, 1-9.

Raven JA. 1988. The iron and molybdenum use efficiencies of plant growth with different energy, carbon and nitrogen sources. New Phytologist 109, 279-287. 
Remy E, Cabrito TR, Batista RA, Hussein MAM, Teixeira MC, Athanasiadis A, Sá-Correia I, Duque P. 2014. Intron retention in the 5'UTR of the novel ZIF2 transporter enhances translation to promote zinc tolerance in arabidopsis. PLoS Genetics 10, e1004375.

Ricachenevsky FK, Menguer PK, Sperotto RA, Fett JP. 2015. Got to hide your Zn away: Molecular control of $\mathrm{Zn}$ accumulation and biotechnological applications. Plant Science 236, 1-17.

Robinson NJ, Procter CM, Connolly EL, Lou Guerinot M. 1999. A ferric-chelate reductase for iron uptake from soils. Nature 397, 694-697.

Rodríguez-Celma J, Chou H, Kobayashi T, Long TA, Balk J. 2019. Hemerythrin E3 Ubiquitin Ligases as Negative Regulators of Iron Homeostasis in Plants. Frontiers in Plant Science 10, 98.

Rogers EE, Guerinot ML. 2002. FRD3, a member of the multidrug and toxin efflux family, controls iron deficiency responses in Arabidopsis. The Plant Cell 14, 1787-1799.

Roschzttardtz H, Grillet L, Isaure M-P, Conéjéro G, Ortega R, Curie C, Mari S. 2011. Plant cell nucleolus as a hot spot for iron. The Journal of Biological Chemistry 286, 27863-27866.

Rouached H, Rhee SY. 2017. System-level understanding of plant mineral nutrition in the big data era. Current Opinion in Systems Biology 4, 71-77.

Rubio V, Linhares F, Solano R, Martín AC, Iglesias J, Leyva A, Paz-Ares J. 2001. A conserved MYB transcription factor involved in phosphate starvation signaling both in vascular plants and in unicellular algae. Genes \& Development 15, 2122-2133.

Ryan PR, Delhaize E, Jones DL. 2001. Function and mechanism of organic anion exudation from plant roots. Annual Review of Plant Physiology and Plant Molecular Biology 52, 527-560.

Saenchai C, Bouain N, Kisko M, Prom-U-Thai C, Doumas P, Rouached H. 2016. The Involvement of OsPHO1;1 in the Regulation of Iron Transport Through Integration of Phosphate and Zinc Deficiency Signaling. Frontiers in Plant Science 7, 396.

Santi S, Schmidt W. 2009. Dissecting iron deficiency-induced proton extrusion in Arabidopsis roots. New Phytologist 183, 1072-1084.

Sarret G, Saumitou-Laprade P, Bert V, Proux O, Hazemann J-L, Traverse A, Marcus MA, Manceau A. 2002. Forms of zinc accumulated in the hyperaccumulator Arabidopsis halleri. Plant Physiology 130, 1815-1826.

Satbhai SB, Setzer C, Freynschlag F, Slovak R, Kerdaffrec E, Busch W. 2017. Natural allelic variation of FRO2 modulates Arabidopsis root growth under iron deficiency. Nature Communications 8, 15603.

Schaaf G, Honsbein A, Meda AR, Kirchner S, Wipf D, von Wirén N. 2006. AtIREG2 encodes a tonoplast transport protein involved in iron-dependent nickel detoxification in Arabidopsis thaliana roots. The Journal of Biological Chemistry 281, 25532-25540.

Schaaf G, Ludewig U, Erenoglu BE, Mori S, Kitahara T, von Wirén N. 2004. ZmYS1 functions as a protoncoupled symporter for phytosiderophore- and nicotianamine-chelated metals. The Journal of Biological 
Chemistry 279, 9091-9096.

Schaaf G, Schikora A, Häberle J, Vert G, Ludewig U, Briat J-F, Curie C, von Wirén N. 2005. A putative function for the Arabidopsis Fe-Phytosiderophore transporter homolog AtYSL2 in $\mathrm{Fe}$ and $\mathrm{Zn}$ homeostasis. Plant \& Cell Physiology 46, 762-774.

Schaedler TA, Thornton JD, Kruse I, Schwarzländer M, Meyer AJ, van Veen HW, Balk J. 2014. A Conserved Mitochondrial ATP-binding Cassette Transporter Exports Glutathione Polysulfide for Cytosolic Metal Cofactor Assembly. Journal of Biological Chemistry 289, 23264-23274.

Scheepers M, Spielmann J, Boulanger M, Carnol M, Bosman B, De Pauw E, Goormaghtigh E, Motte P, Hanikenne M. 2020. Intertwined metal homeostasis, oxidative and biotic stress responses in the Arabidopsis frd3 mutant. The Plant Journal 102, 34-52.

Schoffman H, Lis H, Shaked Y, Keren N. 2016. Iron-Nutrient Interactions within Phytoplankton. Frontiers in Plant Science 7, 1223.

Schuler M, Keller A, Backes C, Philippar K, Lenhof H-P, Bauer P. 2011. Transcriptome analysis by GeneTrail revealed regulation of functional categories in response to alterations of iron homeostasis in Arabidopsis thaliana. BMC Plant Biology 11, 87.

Schuler M, Rellán-Álvarez R, Fink-Straube C, Abadía J, Bauer P. 2012. Nicotianamine functions in the Phloem-based transport of iron to sink organs, in pollen development and pollen tube growth in Arabidopsis. The Plant Cell 24, 2380-2400.

Schvartzman MS, Corso M, Fataftah N, Scheepers M, Nouet C, Bosman B, Carnol M, Motte P, Verbruggen N, Hanikenne M. 2018. Adaptation to high zinc depends on distinct mechanisms in metallicolous populations of Arabidopsis halleri. New Phytologist 218, 269-282.

Shahzad Z, Eaglesfield R, Carr C, Amtmann A. 2020. Cryptic variation in RNA-directed DNA-methylation controls lateral root development when auxin signalling is perturbed. Nature Communications 11, 218.

Shahzad Z, Rouached H, Rakha A. 2014. Combating mineral malnutrition through iron and zinc biofortification of cereals. Comprehensive Reviews in Food Science and Food Safety 13, 329-346.

Shanmugam V, Lo J-C, Wu C-L, Wang S-L, Lai C-C, Connolly EL, Huang J-L, Yeh K-C. 2011. Differential expression and regulation of iron-regulated metal transporters in Arabidopsis halleri and Arabidopsis thaliana--the role in zinc tolerance. New Phytologist 190, 125-137.

Shanmugam V, Lo J-C, Yeh K-C. 2013. Control of Zn uptake in Arabidopsis halleri: a balance between Zn and Fe. Frontiers in Plant Science 4, 281.

Shanmugam V, Tsednee M, Yeh K-C. 2012. ZINC TOLERANCE INDUCED BY IRON 1 reveals the importance of glutathione in the cross-homeostasis between zinc and iron in Arabidopsis thaliana. The Plant Journal 69, 1006-1017.

Shikanai T, Müller-Moulé P, Munekage Y, Niyogi KK, Pilon M. 2003. PAA1, a P-type ATPase of Arabidopsis, functions in copper transport in chloroplasts. The Plant Cell 15, 1333-1346. 
Shi R, Melzer M, Zheng S, Benke A, Stich B, von Wirén N. 2018. Iron Retention in Root Hemicelluloses Causes Genotypic Variability in the Tolerance to Iron Deficiency-Induced Chlorosis in Maize. Frontiers in Plant Science 9, 557.

Shinozaki D, Merkulova EA, Naya L, Horie T, Kanno Y, Seo M, Ohsumi Y, Masclaux-Daubresse C, Yoshimoto K. 2020. Autophagy Increases Zinc Bioavailability to Avoid Light-Mediated Reactive Oxygen Species Production under Zinc Deficiency. Plant Physiology 182, 1284-1296.

Sinclair SA, Krämer U. 2012. The zinc homeostasis network of land plants. Biochimica et Biophysica Acta 1823, 1553-1567.

Smetacek V, Klaas C, Strass VH, et al. 2012. Deep carbon export from a Southern Ocean iron-fertilized diatom bloom. Nature 487, 313-319.

Spijkerman E, Behrend H, Fach B, Gaedke U. 2018. Decreased phosphorus incorporation explains the negative effect of high iron concentrations in the green microalga Chlamydomonas acidophila. The Science of the Total Environment 626, 1342-1349.

Stohs SJ, Bagchi D. 1995. Oxidative mechanisms in the toxicity of metal ions. Free Radical Biology \& Medicine 18, 321-336.

Strzepek RF, Harrison PJ. 2004. Photosynthetic architecture differs in coastal and oceanic diatoms. Nature 431, 689-692.

Sunda WG. 2012. Feedback Interactions between Trace Metal Nutrients and Phytoplankton in the Ocean. Frontiers in Microbiology 3, 204.

Sunda WG, Swift DG, Huntsman SA. 1991. Low iron requirement for growth in oceanic phytoplankton. Nature 351, 55-57.

Suzuki M, Takahashi M, Tsukamoto T, et al. 2006. Biosynthesis and secretion of mugineic acid family phytosiderophores in zinc-deficient barley. The Plant Journal 48, 85-97.

Suzuki M, Tsukamoto T, Inoue H, Watanabe S, Matsuhashi S, Takahashi M, Nakanishi H, Mori S, Nishizawa NK. 2008. Deoxymugineic acid increases Zn translocation in Zn-deficient rice plants. Plant Molecular Biology 66, 609-617.

Takahashi R, Ishimaru Y, Nakanishi H, Nishizawa NK. 2011a. Role of the iron transporter OsNRAMP1 in cadmium uptake and accumulation in rice. Plant Signaling \& Behavior 6, 1813-1816.

Takahashi R, Ishimaru Y, Senoura T, Shimo H, Ishikawa S, Arao T, Nakanishi H, Nishizawa NK. $2011 b$. The OsNRAMP1 iron transporter is involved in $\mathrm{Cd}$ accumulation in rice. Journal of Experimental Botany 62, 4843-4850.

Talke IN, Hanikenne M, Krämer U. 2006. Zinc-dependent global transcriptional control, transcriptional deregulation, and higher gene copy number for genes in metal homeostasis of the hyperaccumulator Arabidopsis halleri. Plant Physiology 142, 148-167.

Tan Y-F, O’Toole N, Taylor NL, Millar AH. 2010. Divalent metal ions in plant mitochondria and their role 
in interactions with proteins and oxidative stress-induced damage to respiratory function. Plant Physiology 152, 747-761.

Terry N, Abadia J. 1986. Function of iron in chloroplasts. Journal of Plant Nutrition 9, 609-646.

Teschner J, Lachmann N, Schulze J, Geisler M, Selbach K, Santamaria-Araujo J, Balk J, Mendel RR, Bittner F. 2010. A novel role for Arabidopsis mitochondrial ABC transporter ATM3 in molybdenum cofactor biosynthesis. Plant Cell 22, 468-480.

Thibaud M-C, Arrighi J-F, Bayle V, Chiarenza S, Creff A, Bustos R, Paz-Ares J, Poirier Y, Nussaume L. 2010. Dissection of local and systemic transcriptional responses to phosphate starvation in Arabidopsis. The Plant Journal 64, 775-789.

Thomine S, Vert G. 2013. Iron transport in plants: better be safe than sorry. Current Opinion in Plant Biology 16, 322-327.

Thomine S, Wang R, Ward JM, Crawford NM, Schroeder JI. 2000. Cadmium and iron transport by members of a plant metal transporter family in Arabidopsis with homology to Nramp genes. Proceedings of the National Academy of Sciences of the United States of America 97, 4991-4996.

Ticconi CA, Lucero RD, Sakhonwasee S, Adamson AW, Creff A, Nussaume L, Desnos T, Abel S. 2009. ERresident proteins PDR2 and LPR1 mediate the developmental response of root meristems to phosphate availability. Proceedings of the National Academy of Sciences of the United States of America 106, 14174-14179.

Tsednee M, Castruita M, Salomé PA, et al. 2019. Manganese co-localizes with calcium and phosphorus in Chlamydomonas acidocalcisomes and is mobilized in manganese-deficient conditions. Journal of Biological Chemistry 294, 17626-17641.

Uraguchi S, Weber M, Clemens S. 2019. Elevated root nicotianamine concentrations are critical for Zn hyperaccumulation across diverse edaphic environments. Plant, Cell \& Environment 42, 2003-2014.

Urzica El, Casero D, Yamasaki H, et al. 2012. Systems and trans-system level analysis identifies conserved iron deficiency responses in the plant lineage. The Plant Cell 24, 3921-3948.

Vert G, Barberon M, Zelazny E, Séguéla M, Briat J-F, Curie C. 2009. Arabidopsis IRT2 cooperates with the high-affinity iron uptake system to maintain iron homeostasis in root epidermal cells. Planta 229, 1171-1179.

Vert G, Grotz N, Dédaldéchamp F, Gaymard F, Guerinot ML, Briat J-F, Curie C. 2002. IRT1, an Arabidopsis transporter essential for iron uptake from the soil and for plant growth. The Plant Cell 14, 1223-1233.

Vigani G, Hanikenne M. 2018. Metal Homeostasis in Plant Mitochondria. Annual Plant Reviews online, 111-142.

von Wirén N, Klair S, Bansal S, Briat JF, Khodr H, Shioiri T, Leigh RA, Hider RC. 1999. Nicotianamine chelates both $\mathrm{Fe}^{\mathrm{III}}$ and $\mathrm{Fe}$ ". Implications for metal transport in plants. Plant Physiology 119, 1107-1114. 
von Wirén N, Marschner H, Römheld V. 1996. Roots of Iron-Efficient Maize also Absorb Phytosiderophore-Chelated Zinc. Plant Physiology 111, 1119-1125.

Wairich A, de Oliveira BHN, Arend EB, Duarte GL, Ponte LR, Sperotto RA, Ricachenevsky FK, Fett JP. 2019. The Combined Strategy for iron uptake is not exclusive to domesticated rice (Oryza sativa). Scientific Reports 9, 16144.

Ward JT, Lahner B, Yakubova E, Salt DE, Raghothama KG. 2008. The effect of iron on the primary root elongation of Arabidopsis during phosphate deficiency. Plant Physiology 147, 1181-1191.

Waters BM, Chu H-H, Didonato RJ, Roberts LA, Eisley RB, Lahner B, Salt DE, Walker EL. 2006. Mutations in Arabidopsis yellow stripe-like1 and yellow stripe-like 3 reveal their roles in metal ion homeostasis and loading of metal ions in seeds. Plant Physiology 141, 1446-1458.

Waters BM, McInturf SA, Stein RJ. 2012. Rosette iron deficiency transcript and microRNA profiling reveals links between copper and iron homeostasis in Arabidopsis thaliana. Journal of Experimental Botany 63, 5903-5918.

Weber M, Harada E, Vess C, Roepenack-Lahaye E v., Clemens S. 2004. Comparative microarray analysis of Arabidopsis thaliana and Arabidopsis halleri roots identifies nicotianamine synthase, a ZIP transporter and other genes as potential metal hyperaccumulation factors. The Plant Journal 37, 269-281.

Willems G, Frérot H, Gennen J, Salis P, Saumitou-Laprade P, Verbruggen N. 2010. Quantitative trait loci analysis of mineral element concentrations in an Arabidopsis halleri x Arabidopsis lyrata petraea F2 progeny grown on cadmium-contaminated soil. New Phytologist 187, 368-379.

Wu H, Ling H-Q. 2019. FIT-Binding Proteins and Their Functions in the Regulation of Fe Homeostasis. Frontiers in Plant Science 10, 844.

Wykoff DD, Grossman AR, Weeks DP, Usuda H, Shimogawara K. 1999. Psr1, a nuclear localized protein that regulates phosphorus metabolism in Chlamydomonas. Proceedings of the National Academy of Sciences of the United States of America 96, 15336-15341.

Yang TJW, Lin W-D, Schmidt W. 2010. Transcriptional profiling of the Arabidopsis iron deficiency response reveals conserved transition metal homeostasis networks. Plant Physiology 152, 2130-2141.

Yokosho K, Yamaji N, Ma JF. 2016. OsFRDL1 expressed in nodes is required for distribution of iron to grains in rice. Journal of Experimental Botany 67, 5485-5494.

Yokosho K, Yamaji N, Ueno D, Mitani N, Ma JF. 2009. OsFRDL1 is a citrate transporter required for efficient translocation of iron in rice. Plant Physiology 149, 297-305.

Yoneyama T, Ishikawa S, Fujimaki S. 2015. Route and Regulation of Zinc, Cadmium, and Iron Transport in Rice Plants (Oryza sativa L.) during Vegetative Growth and Grain Filling: Metal Transporters, Metal Speciation, Grain Cd Reduction and $\mathrm{Zn}$ and Fe Biofortification. International Journal of Molecular sciences 16, 19111-19129.

Zargar SM, Kurata R, Inaba S, Oikawa A, Fukui R, Ogata Y, Agrawal GK, Rakwal R, Fukao Y. 2015. Quantitative proteomics of Arabidopsis shoot microsomal proteins reveals a cross-talk between excess 
zinc and iron deficiency. Proteomics 15, 1196-1201.

Zhang Y, Xu Y-H, Yi H-Y, Gong J-M. 2012. Vacuolar membrane transporters OsVIT1 and OsVIT2 modulate iron translocation between flag leaves and seeds in rice. The Plant Journal 72, 400-410.

Zuchi S, Cesco S, Varanini Z, Pinton R, Astolfi S. 2009. Sulphur deprivation limits Fe-deficiency responses in tomato plants. Planta 230, 85-94.

Zuchi S, Watanabe M, Hubberten H-M, et al. 2015. The Interplay between Sulfur and Iron Nutrition in Tomato. Plant Physiology 169, 2624-2639. 


\section{Figure legends}

Figure 1. Primary root growth in Arabidopsis depends on iron and phosphate availability. (A) Under phosphate sufficiency (+P), iron deficiency (-Fe) or excess (++Fe) inhibit primary root growth (PRG) compared to Fe sufficiency (+Fe). The PRG responses to $-\mathrm{Fe}$ and ++Fe involve the FRO2 (FERRIC REDUCTASE OXIDASE 2) and GSNOR (S-NITROSOGLUTATHIONE-REDUCTASE) genes, respectively. (B) Simultaneous P deficiency (-P) and Fe sufficiency (+Fe) inhibits PRG compared to Fe sufficiency (+Fe). This response involves the LPR1 (cell wall-targeted FERROOXIDASE), PDR2 (P5-type ATPase), STOP1 (SENSITIVE TO PROTON RHIZOTOXICITY), encoding a transcription factor, and ALMT1 (ALUMINUM ACTIVATED MALATE TRANSPORTER 1) genes. PRG is similar to Fe sufficiency upon simultaneous $\mathrm{P}(-\mathrm{P})$ and $\mathrm{Fe}(-\mathrm{Fe})$ deficiencies and this response may be controlled by the AT1G51310, AT2G36200, AT4G09940 and AT5G16580 candidate genes (Bouain et al., 2019a). PRG under -P and Fe excess (++Fe) remains to be studied and is shown by a question mark (?).

Figure 2. Iron and micronutrient uptake and trafficking interactions in Arabidopsis and rice roots. Only the interface with the rhizosphere (left) and the xylem (right) is detailed. (A) Arabidopsis. In dicots, iron uptake from the soil relies on a reduction strategy (Strategy I). The localization of IRT1 and NRAMP1 was shown to be dynamic, between plasma membrane and endo-membranes (see text). Metal ligands in the xylem, with their relative abundance represented by different font size, are based on data in Pisum sativum (Flis et al., 2016). (B) Rice. In rice, as in grasses, iron uptake from the soil relies on a reduction strategy (Strategy II). Rice is however an exception among grasses as it also uses part of the Strategy I. The mechanisms shared by all grasses for iron uptake are represented in red, whereas the function of IRT1 specific to rice is in orange. Note that the biosynthesis of MAs from SAM may take place in rough endoplasmic reticulum-derived vesicles, which are not represented here (Kobayashi et al., 2019). Red: uptake processes taking place at the root epidermis, including processes related to the IRT1 lack of specificity in Arabidopsis (A); Purple: intracellular and long distance trafficking processes; Green: chelator and chelator transporter-related processes. Vacuoles and vesicles are represented by green and yellow bubbles, respectively. The intracellular green arrow represents symplastic mouvements of metal chelates. Note that phenolics secretion by roots into the rhizosphere is not represented (Kobayashi et al., 2019). Most of these processes are induced by iron deficiency under the control of complex and multi-layer regulatory mechanisms (see text). Hypothetical processes are labelled with a question mark (?). AHA2: ARABIDOPSIS H+-ATPASE 2; Cit: Citrate; ENA1: EFFLUX TRANSPORTER OF NA 1; FRD(L): FERRIC REDUCTASE DEFECTIVE(-LIKE); FPN: FERROPORTIN; FRO2: FERRIC REDUCTASE-OXIDASE 2; IRT: IRONREGULATED TRANSPORTER; HMA3: HEAVY METAL ATPASE 3; MA: MUGINEIC ACID FAMILY 
PHYTOSIDEROPHORES; MTP: METAL TOLERANCE PROTEIN; NA, NICOTIANAMINE; NRAMP: NATURAL RESISTANCE-ASSOCIATED MACROPHAGE PROTEIN; PEZ1: PHENOLICS EFFLUX ZERO 1; SAM: SADENOSYL-L-METHIONINE; TOM: TRANSPORTER OF MUGINEIC ACID FAMILY PHYTOSIDEROPHORES; YSL: YELLOW-STRIPE-LIKE; ZIF1: ZINC-INDUCED FACILITATOR 1.

Box1. Fe and nutrient interplay in eukaryotic algae

Land plants frequently come to mind when talking about photosynthetic organisms and the heterogeneous group known as algae is often overlooked. Algae is an umbrella term used to describe a polyphyletic group of (mostly aquatic and photosynthetic) eukaryotes (Prasanna and Kaushik, 2010; Brodie et al., 2017) that acquired photosynthesis through primary or secondary endosymbiosis (Keeling, 2013; Brodie et al., 2017). Algae produce $~ 50 \%$ of oxygen on earth and provide multiple ecosystem and economic services to humans (Brodie et al., 2017). Their diverse evolutionary origins and diverse habitats, characterized by different Fe availability give ample room for originality and innovation in Fe homeostasis and its interactions with other nutrients. In this box, we will highlight a few examples of the peculiarities found in algae.

Fe is known to limit algae growth in marine environments (Sunda, 2012; Smetacek et al., 2012; Brodie et al., 2017) as well as in freshwater ecosystems (Liu et al., 2018). Fe is a particularly limiting nutrient in open ocean, the so-called high-nutrient, low-carbon areas (Boyd et al., 2007; Morrissey and Bowler, 2012), leading to adaptation of the photosynthetic machinery in algae inhabiting those areas (Strzepek and Harrison, 2004; Cardol et al., 2008). Fe uptake pathways are very diversified in algae. In Chlamydomonas, $\mathrm{Fe}^{3+}$ is first reduced by ferric chelate reductases, then high affinity $\mathrm{Fe}$ uptake is mediated by a multicopper ferroxidase that reoxidizes $\mathrm{Fe}^{2+}$ to $\mathrm{Fe}^{3+}$ and an Fe permease that transports $\mathrm{Fe}^{3+}$ into the cell, as it occurs in yeast and mammals. This re-oxidation step, and subsequent uptake of $\mathrm{Fe}^{3+}$, confers a high metal specificity to this high-affinity Fe uptake system (La Fontaine et al., 2002; Herbik et al., 2002; Merchant et al., 2006). However, two ZIP homolog proteins, named IRT1 and IRT2, are also induced by Fe deficiency in Chlamydomonas and expected to form a parallel pathway of $\mathrm{Fe}^{2+}$ transport (Hanikenne et al., 2009; Urzica et al., 2012). Cd exposure results in the strong induction of both uptake pathways, which enables to limit the impact of $\mathrm{Cd}$ on Fe homeostasis but comes at the cost of higher Cd uptake (Thiriet-Rupert and Hanikenne, unpublished). This response is in part controlled by the concerted action of a bHLH transcription factor and the main Pi transcriptional regulator, PSR1 (PHOSPHATE STARVATION RESPONSE 1) (Thiriet-Rupert and Hanikenne, unpublished), an ortholog of the 
plant PHR1 transcription factor (Wykoff et al., 1999; Rubio et al., 2001; Moseley et al., 2006) (see main text). This indicates that, as in monocots, Fe homeostasis is impacted by other metal cations also in organisms relying partly on $\mathrm{Fe}^{3+}$ uptake.

Several other algal species also re-oxidize $\mathrm{Fe}^{2+}$ into $\mathrm{Fe}^{3+}$ and, in addition, possess, as in animals, transferrin-like proteins responsible for $\mathrm{Fe}^{3+}$ uptake (e.g. the halophyte alga Dunaliella salina and the sea weed Ulva mutabilis) (Paz et al., 2007; Blaby-Haas and Merchant, 2017; De Clerck et al., 2018). As plants that export/secrete siderophores or phenolic compounds to mobilize and/or scavenge $\mathrm{Fe}^{3+}$ in the soil, algae also employ diverse strategies to capture Fe from their environment: using extracellular Fechelating proteins, such as the secreted FEA1 and FEA2 (Fe-Assimilation) in Chlamydomonas or the plasma-membrane anchored ISIP2a (Fe Starvation-Inducible Protein) in Phaeodactylum tricornutum (Allen et al., 2007; Morrissey et al., 2015; Blaby-Haas and Merchant, 2017); or relying on bacterial siderophores, as suggested in U. mutabilis and other species (Hopkinson and Morel, 2009; De Clerck et al., 2018). FEAs and ISIP2a genes are induced by Fe deficiency (but not by deficiencies of other metals) (Allen et al., 2007; Morrissey et al., 2015), and ISIP2a was actually shown to bind Fe (Morrissey et al., 2015). Whether these Fe scavenging strategies are influenced by interactions with other nutrients has not been examined in details.

Copper $(\mathrm{Cu})$ and $\mathrm{Zn}$ also play important roles in Fe homeostasis in algae. In several species, such as Chlamydomonas, Thalassiosira oceanica and D. salina, multicopper oxidases (MCO) take part in high affinity Fe uptake (Maldonado et al., 2006; Paz et al., 2007; Blaby-Haas and Merchant, 2017). In contrast, in the marine alga Ostreococcus tauri, where Fe uptake is dependent on an IRT1-like protein, $\mathrm{Zn}$, and not $\mathrm{Cu}$, appears to be required for proper Fe-uptake and its regulation (Lelandais et al., 2016). An interaction between Zn and the regulation of IRT1 also occurs in Chlamydomonas where an induction of IRT1 takes place under Zn-deprivation (Blaby-Haas and Merchant, 2017). In addition, Cu-based plastocyanin and Fe-based cytochrome $c_{6}$ are interchangeable in the photosynthetic electron transfer chain in green algae such as Chlamydomonas. Upon $\mathrm{Cu}$ starvation, plastocyanin can be replaced by cytochrome $c_{6}$ as part of a Cu-saving program (Howe et al., 2006; Merchant, 2007). An extreme example of this is the red alga Cyanidioschizon merolae, which inhabits acidic Fe-rich low-Cu hot springs and completely lacks plactocyanin (Hanikenne et al., 2005a). It is also lacking MCOs, but possesses multiple Fe permeases (Blaby-Haas and Merchant, 2012; Hanikenne et al., 2005a). 
Cytosolic calcium (Ca) signaling was shown to be crucial for the response to changes of environmental Fe concentration in the diatom Phaeodactylum tricornutum (Falciatore et al., 2000). Inside the cells, Ca interacts with Fe storage in vacuole-like acidocalcisomes in several algal species, including Chlamydomonas and the red alga Cyanidioschyzon merolae (Blaby-Haas and Merchant, 2014). In addition to $\mathrm{Fe}$, these dense acidic organelles, made mostly of $\mathrm{Ca}$ and polyphosphate complexes, constitute the main storage compartment for divalent cations such as $\mathrm{Zn}, \mathrm{Mn}$ and $\mathrm{Cd}$ (Docampo et al., 2005; Penen et al., 2017; Tsednee et al., 2019).

Although $\mathrm{N}$ availability is key for biomass production, most photosynthetic organisms cannot fix $\mathrm{N}$ from the massive reservoir that is atmospheric $\mathrm{N}_{2}$ (Boyd and Peters, 2013). In soil, legumes can however form a symbiosis with a diazotrophic bacteria in order to fix $\mathrm{N}_{2}$ (Mus et al., 2016). Hence, the plant Medicago truncatula provides Fe to the symbiont, ensuring nitrogenase activity in the symbiont (GonzálezGuerrero et al., 2014; Escudero et al., 2020). Algae can use different sources of $\mathrm{N}$ and their Fe requirement varies in function of the $\mathrm{N}$ source (Raven, 1988). Indeed, diazotrophic cyanobacteria have a higher Fe requirement than algae growing on nitrate, which is superior to those growing on ammonia. Ammonia can be readily used from the media, but nitrate reduction and $\mathrm{N}_{2}$ fixation require $\mathrm{Fe}$ as cofactor and source of reductive power (Schoffman et al., 2016).

Finally, P and Fe also interact both in fresh and marine water (Benitez-Nelson, 2000; Qiu et al., 2020). In freshwater, both Fe concentration and speciation have a significant impact on P uptake in Scenedesmus quadricauda (Qiu et al., 2020). This contrasts with very acidic lakes, where pH is usually below 4 rendering Fe more bioavailable. There, by forming less bioavailable Fe-P complexes, Fe promotes $\mathrm{P}$ deficiency, even when $\mathrm{P}$ concentration is not limiting, possibly contributing to low primary productivity in Fe-rich acidic lakes (Spijkerman et al., 2018). Algae species found in these habitats, such as Chlamydomonas acidophila, can tolerate approximately twenty times higher amount of Fe compared to neutrophile species, such as Chlamydomonas (Spijkerman et al., 2018). 
A

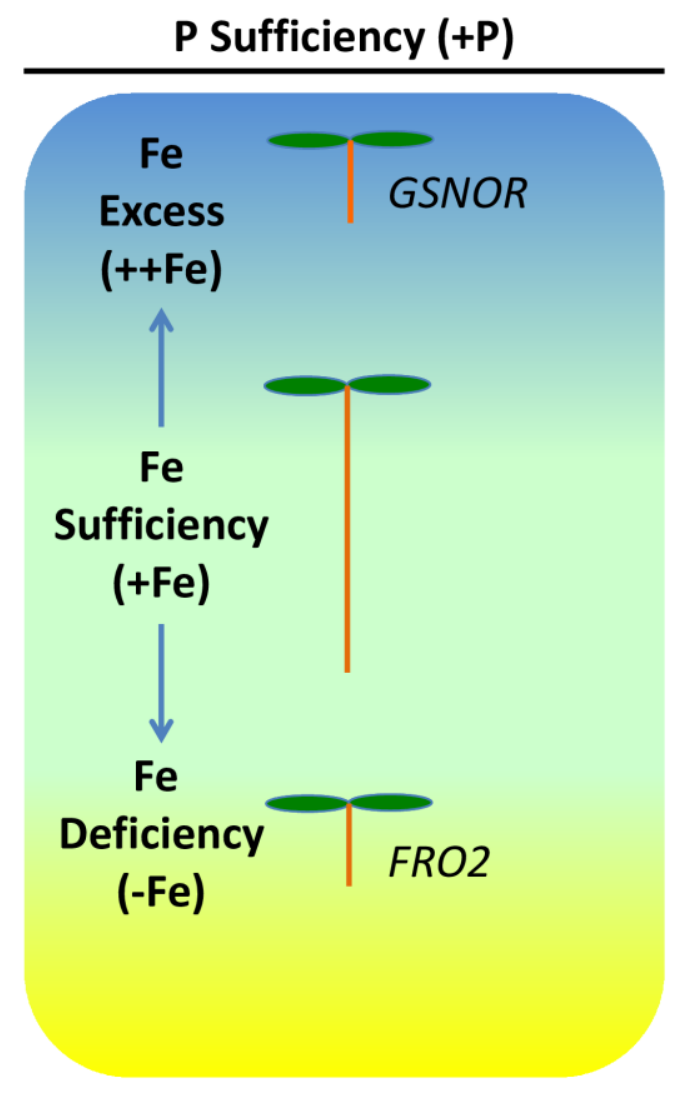

B

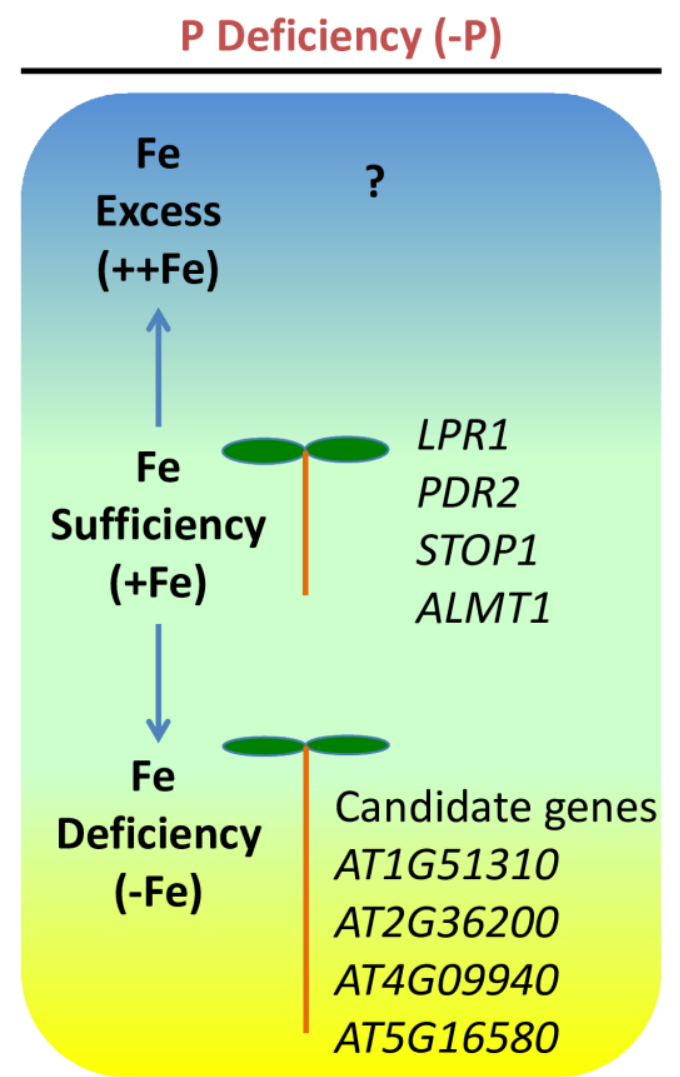

Figure 1 

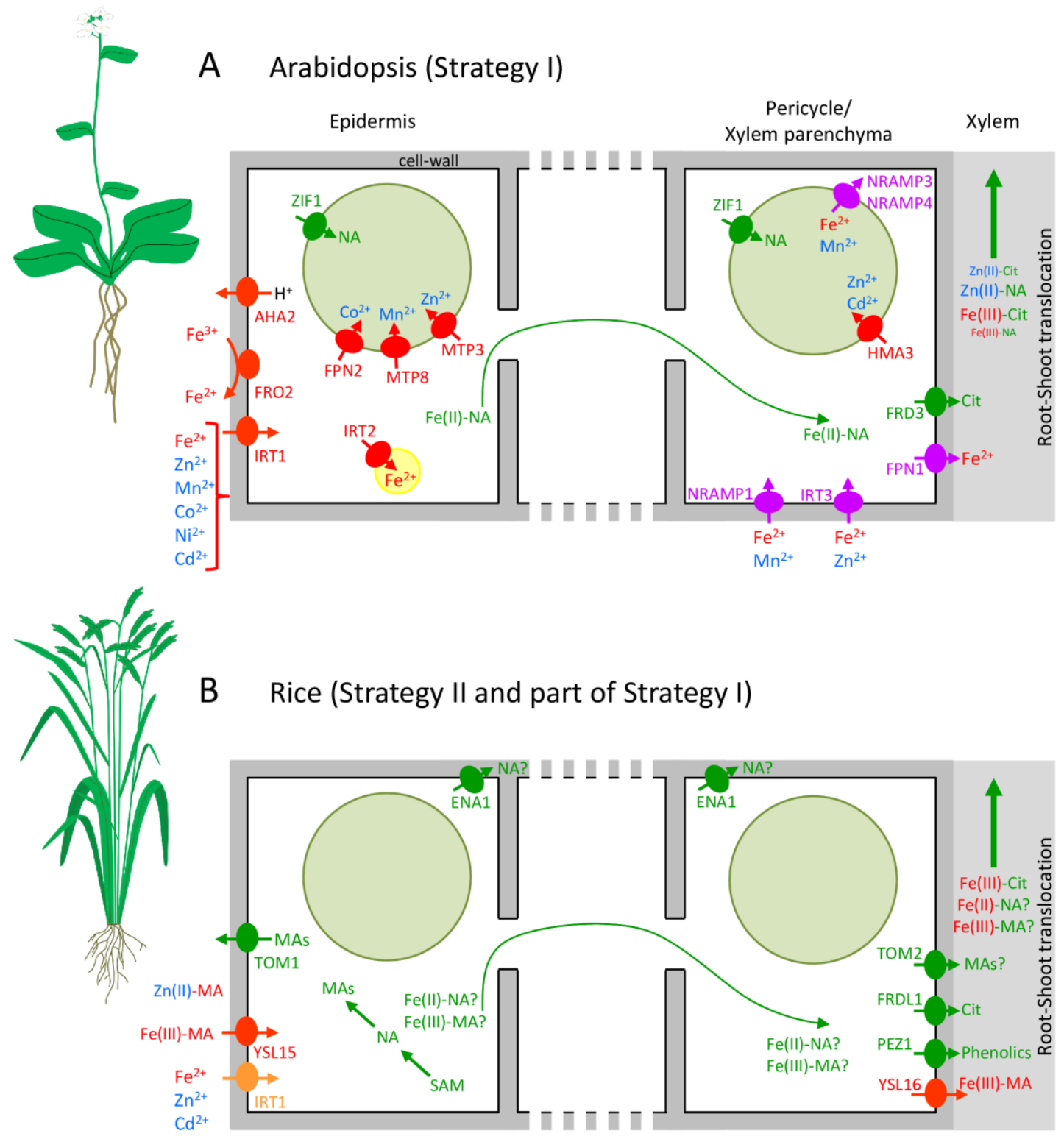

Figure 2 